\title{
Use of calcitriol to maintain postpartum blood calcium and improve immune function in dairy cows
}

\author{
A. Vieira-Neto, ${ }^{\star} \dagger$ I. R. P. Lima, ${ }^{*}$ F. Lopes Jr., ${ }^{*}$ C. Lopera, ${ }^{*}$ R. Zimpel, ${ }^{*}$ L. D. P. Sinedino, ${ }^{*} \dagger$ K. C. Jeong, \\ K. Galvão,†‡ W. W. Thatcher, ${ }^{*} \dagger$ C. D. Nelson, ${ }^{*}$ and J. E. P. Santos ${ }^{*} \dagger^{1}$ \\ *Department of Animal Sciences, \\ †DH Barron Reproductive and Perinatal Biology Research Program, and \\ ‡Department of Large Animal Clinical Sciences, University of Florida, Gainesville 32611
}

\section{ABSTRACT}

Our objectives were to determine the effects of an injectable formulation of calcitriol on mineral metabolism and immune function in postpartum Holstein cows that received an acidogenic diet prepartum to minimize hypocalcemia. In experiment 1 , cows within $6 \mathrm{~h}$ of calving received calcitriol $(0,200$, or $300 \mu \mathrm{g})$ to determine the dose needed to increase plasma concentrations of $\mathrm{Ca} ; 300 \mu \mathrm{g}$ was sufficient to sustain $\mathrm{Ca}$ for at least 3 d. In experiment 2, multiparous cows were assigned randomly to receive only vehicle (control, $\mathrm{n}=25$ ) or $300 \mu \mathrm{g}$ of calcitriol $(\mathrm{n}=25)$ subcutaneously within the first $6 \mathrm{~h}$ after calving. Blood was sampled before treatment and $12 \mathrm{~h}$ later, then daily until $15 \mathrm{~d}$ in milk (DIM), and analyzed for concentrations of ionized Ca (iCa), total $\mathrm{Ca}(\mathrm{tCa})$, total $\mathrm{Mg}(\mathrm{tMg})$, and total $\mathrm{P}(\mathrm{tP})$, metabolites, and hormones. Urine was sampled in the first 7 DIM and analyzed for concentrations of tCa, $\mathrm{tMg}$, and creatinine. Neutrophil function was evaluated in the first week postpartum. Dry matter intake and production performance were evaluated for the first 36 DIM. Calcitriol administration increased concentrations of calcitriol in plasma within $12 \mathrm{~h}$ of application from 51 to $427 \mathrm{pg} / \mathrm{mL}$, which returned to baseline within $5 \mathrm{~d}$. Concentrations of $\mathrm{iCa}$ and tCa increased $24 \mathrm{~h}$ after treatment with calcitriol. Concentrations of $\mathrm{iCa}($ control $=1.08$ vs. calcitriol $=1.20 \mathrm{mM})$, tCa $($ control $=2.23$ vs. calcitriol $=2.33 \mathrm{mM})$, and $\mathrm{tP}$ (control $=1.47$ vs. calcitriol $=1.81 \mathrm{~m} M$ ) remained elevated in cows treated with calcitriol until 3,5 , and 7 DIM, respectively, whereas concentration of tMg (control $=0.76$ vs. calcitriol $=0.67 \mathrm{mM}$ ) was less in calcitriol cows than control cows until 3 DIM. Concentrations of parathyroid hormone decreased in calcitriol cows compared with control cows (control $=441$ vs. calcitriol

Received December 21, 2016.

Accepted March 16, 2017.

${ }^{1}$ Corresponding author: jepsantos@ufl.edu
$=336 \mathrm{pg} / \mathrm{mL})$. Calcitriol tended to increase plasma concentrations of $\beta$-hydroxybutyrate and serotonin, but concentrations of glucose, nonesterified fatty acids, and C-telopeptide of type I collagen in plasma did not differ between treatments. Cows treated with calcitriol excreted more urinary tCa (control $=0.5$ vs. calcitriol $=2.1 \mathrm{~g} / \mathrm{d}$ ) and $\mathrm{tMg}$ (control $=4.5$ vs. calcitriol $=5.0$ $\mathrm{g} / \mathrm{d}$ ) in the first 7 and 2 DIM, respectively, than control cows. Compared with control, calcitriol improved the proportion of neutrophils with oxidative burst (control $=31.9$ vs. calcitriol $=40.6 \%$ ), mean fluorescence intensity for oxidative burst (control $=90,900$ vs. calcitriol $=99,746)$, and mean fluorescence intensity for phagocytosis (control $=23,887$ vs. calcitriol $=28,080$ ) Dry matter intake, yields of milk, and milk components did not differ between treatments. Administration of $300 \mu \mathrm{g}$ of calcitriol at calving was safe and effective in increasing blood concentration of iCa and plasma concentrations of calcitriol, tCa, and tP for the first $6 \mathrm{~d}$ after treatment, and improved measures of innate immune function in early-lactation Holstein cows.

Key words: calcitriol, dairy cow, hypocalcemia, vitamin $\mathrm{D}$

\section{INTRODUCTION}

A large proportion of dairy cows undergo a period of hypocalcemia with the onset of colostrogenesis and lactation. The large demands for $\mathrm{Ca}$ for colostrum and milk synthesis induce a sudden drop in blood concentrations of ionized (iCa) and total $\mathrm{Ca}(\mathbf{t} \mathbf{C a})$, so that some cows develop clinical hypocalcemia, also known as milk fever (DeGaris and Lean, 2008; Goff, 2014). Normal concentrations of tCa in the blood usually range between 2.2 and $2.7 \mathrm{mM}$, but the onset of lactation results in sequestration of $\mathrm{Ca}$ in the mammary gland before calving (Visek et al., 1953), followed by loss with colostrum secretion, which can represent 7 to 10 times the estimated amount of tCa present in blood of a cow (Horst et al., 2005) and result in decreased blood tCa to concentrations less than $2.2 \mathrm{mM}$. The inability of the 
cow to quickly reestablish concentrations of $\mathrm{iCa}$ and tCa in blood, because of inadequate intestinal absorption, bone resorption, or urinary reabsorption is responsible for the development hypocalcemia in the first days of lactation. Reinhardt et al. (2011) used cutoff values for serum concentrations of tCa of 1.4 to $2.0 \mathrm{~m} M$ to detect cows with subclinical hypocalcemia, and concentrations below $1.4 \mathrm{~m} M$ as an indication of clinical hypocalcemia. Using those cutoff values, the authors reported prevalences of $1 \%$ clinical hypocalcemia and $25 \%$ subclinical hypocalcemia for primiparous cows, and $7 \%$ clinical hypocalcemia and $47 \%$ subclinical hypocalcemia for multiparous cows in the first $48 \mathrm{~h}$ of calving. More recent experiments with cows fed prepartum acidogenic diets also showed a high incidence of subclinical hypocalcemia postpartum of 65 to $69 \%$ (Martinez et al., 2012,2016 ). In those experiments, blood was sampled daily, and the threshold for subclinical hypocalcemia was $2.125 \mathrm{~m} M$, which likely explains the higher values than observed by Reinhardt et al. (2011) despite the acidogenic diets. Cows that develop subclinical and clinical hypocalcemia have subsequent impaired health and reproduction. They are more susceptible to other periparturient disorders such as dystocia and ketosis (Curtis et al., 1983), displaced abomasum (Massey et al., 1993), uterine prolapse (Risco et al., 1984), retained placenta (Melendez et al., 2004), and metritis (Martinez et al., 2012). Thus, susceptibility to periparturient diseases, particularly those affecting the reproductive tract, increases in dairy cows that are unable to maintain blood concentrations of $\mathrm{Ca}$ in early lactation. In fact, it has been reported that both clinical hypocalcemia (Kimura et al., 2006) and subclinical hypocalcemia (Martinez et al., 2014) depress immune function and predispose cows to diseases.

Dietary and therapeutic strategies are available to minimize the risk of hypocalcemia in dairy cattle (DeGaris and Lean, 2008; Goff, 2014; Oetzel and Muller, 2012). One of the most common methods of preventing hypocalcemia is manipulation of the prepartum dietary mineral content by altering the DCAD of the ration. Diets with a negative DCAD induce a compensated metabolic acidosis that promotes increases in iCa and tCa concentrations in the blood of cows immediately after calving (DeGaris and Lean, 2008; Goff, 2014). Still, in spite of such preventative measures, at least $47 \%$ of multiparous cows experience subclinical hypocalcemia in the first $48 \mathrm{~h}$ after calving (Reinhardt et al., 2011). As cows develop subclinical hypocalcemia and the concentration of blood iCa drops, the parathyroid gland rapidly increases secretion of parathyroid hormone (PTH), which activates renal reabsorption of urinary $\mathrm{Ca}$ and osteoclastic bone resorption, and increases renal production of the active form of vitamin $\mathrm{D}_{3}$, calcitriol.
Calcitriol enhances intestinal Ca absorption (Pansu et al., 1983), bone resorption (Kitazawa et al., 2003), and urinary Ca and $\mathrm{P}$ reabsorption (Hoenderop et al., 2001). Several authors have investigated the use of vitamin $\mathrm{D}_{3}$ metabolites to prevent the development of clinical hypocalcemia in dairy cows (Jorgensen et al., 1978; Gast et al., 1979; Allsop and Pauli, 1985). Goff et al. (1988) administered a calcitriol analog intramuscularly to prepartum cows at greater risk of developing clinical hypocalcemia, starting $7 \mathrm{~d}$ before the expected day of calving and repeating every $7 \mathrm{~d}$ until calving. The incidence of clinical hypocalcemia decreased from $85 \%$ in untreated controls to 43 and $29 \%$ in cows that received 100 and $150 \mu \mathrm{g}$ of 24-F-1,25-dihydroxyvitamin $\mathrm{D}_{3}$; however, the repeated treatments prepartum impaired endogenous calcitriol synthesis postpartum in treated cows and eventually resulted in clinical hypocalcemia. Hove and Kristiansen (1982) administered $500 \mu \mathrm{g}$ of calcitriol orally to 15 cows that were predisposed to clinical hypocalcemia and then grouped them according to the day the treatment was administered relative to calving: within $24 \mathrm{~h}$ of calving, 1 to $3 \mathrm{~d}$ before calving, or 4 to $5 \mathrm{~d}$ before calving. A group of 8 cows remained as untreated controls. Administration of calcitriol 1 to $3 \mathrm{~d}$ before calving increased blood $\mathrm{Ca}$ and $\mathrm{P}$ compared with all other groups. An issue with such strategies prepartum is predicting the day of calving so that vitamin $\mathrm{D}_{3}$ metabolites are administered at the proper time. Another option is to use calcitriol immediately after calving in an attempt to prevent any further decline in blood Ca that might occur postpartum.

We hypothesized that an injectable formulation of calcitriol administered in the first hours after parturition would sustain blood concentrations of iCa and tCa and improve measures of immune function in early-lactation cows. The objectives of the present experiment were to determine the effect of an injectable formulation of calcitriol on Ca homeostasis, measures of immune function, energy metabolism, and productive performance in early-lactation dairy cows.

\section{MATERIALS AND METHODS}

Two experiments were conducted at the University of Florida Dairy Unit to characterize the responses to administration of calcitriol in early-lactation multiparous Holstein cows. The experiments were approved by the University of Florida Institutional Animal Care and Use Committee, protocol number 201408679.

\section{Calcitriol Formulation}

A stock solution of calcitriol was prepared by dissolving $10 \mathrm{mg}$ of crystalline powder calcitriol (Cayman 
Chemical, Ann Arbor, MI) with ethanol 99.5\% (1 mL; Sigma-Aldrich, St. Louis, MO). Further dilution of 1 to 10 with ethanol was done on the day of use. The concentration of calcitriol in the ethanol solution was measured by UV absorbance between 200 to $300 \mathrm{~nm}$ (BioTek Synergy HT; BioTek Instruments, Winooski, VT) to ensure that the calcitriol was properly diluted. Briefly, calcitriol in ethanol solution $(1,000 \mu \mathrm{g} / \mathrm{mL})$ was further diluted to concentrations of 100 and 10 $\mu \mathrm{g} / \mathrm{mL}$. Then $200-\mu \mathrm{L}$ aliquots of ethanol $99.5 \%(0 \mu \mathrm{g} /$ $\mathrm{mL}$ of calcitriol), and 10 and $100 \mu \mathrm{g} / \mathrm{mL}$ dilutions of calcitriol were pipetted into duplicate wells of a 96 -well UV transparent plate to measure absorbance at a 264 $\mathrm{nm}$ wavelength, the wavelength that maximized absorbance. Concentration $(c)$ was determined based on the Beer-Lambert Law formula: $A=\varepsilon \times b \times c$, where $A$ was the measured absorbance at $264 \mathrm{~nm}, \varepsilon$ was the molar extinction coefficient for calcitriol $(18,600)$, and $b$ was the path length calculated for the 96-well microplate when $200 \mu \mathrm{L}$ was pipetted into the well $(0.56$ $\mathrm{cm})$, and the molecular weight of calcitriol was 416.63 $\mathrm{g} / \mathrm{mol}$. Therefore, concentration $(c, \mathrm{~g} / \mathrm{L})$ was obtained as follows:

$$
c=\frac{A}{(18,600 \times 0.56)} \times 416.63 .
$$

To prepare the injectable formulation, glyceryl trioctanoate (Sigma-Aldrich) was used as a medium-chain triglyceride vehicle, and 2,6-di-tert-butyl-4-methylphonel (Sigma-Aldrich) as an antioxidant to achieve a $95 \%$ oleaginous solution with calcitriol at a concentration of $50 \mu \mathrm{g} / \mathrm{mL}$. The final solution was mixed continuously using a vortex for at least $20 \mathrm{~min}$. All procedures were done aseptically under a laminar flow hood using autoclaved laboratory materials. A control solution without the calcitriol crystalline powder was prepared following the same steps. Solutions were stored at $8^{\circ} \mathrm{C}$ and used within $14 \mathrm{~d}$. Before administration to cows, the solutions were brought to ambient temperature and mixed thoroughly for $1 \mathrm{~min}$.

\section{Experiment 1}

Experiment 1 was designed to determine the appropriate dose of calcitriol to increase plasma concentrations of $\mathrm{Ca}$ in a sustained manner without subsequent hypocalcemia. Twenty-four multiparous Holstein cows were assigned randomly to receive 1 of 3 treatments within $6 \mathrm{~h}$ of calving. Treatments consisted of a subcutaneous injection in the ischioanal fossa of vehicle only $(0 \mu \mathrm{g}, 8 \mathrm{cows})$, or a solution containing $200 \mu \mathrm{g}$ of calcitriol (9 cows), or $300 \mu \mathrm{g}$ of calcitriol (7 cows). Blood was sampled by puncture of the coccygeal vessels into lithium-heparinized evacuated tubes (Vacutainer; Becton Dickinson, Franklin Lakes, NJ) immediately before administration of treatment, and daily until 15 DIM. Tubes were placed on ice, transported to the laboratory within $30 \mathrm{~min}$, and centrifuged for $15 \mathrm{~min}$ at 2,500 $\times g$ for plasma separation. Plasma samples were transferred to microtubes and stored frozen at $-20^{\circ} \mathrm{C}$ until analysis. Plasma samples were analyzed for concentrations of $\mathrm{tCa}, \mathrm{tP}$, and $\mathrm{tMg}$ as described in experiment 2 .

To assess whether the dose of calcitriol would affect concentrations of calcitriol without the interference of early-lactation hypocalcemia, another 4 multiparous Holstein cows in late lactation received a subcutaneous injection in the ischioanal fossa of $300 \mu \mathrm{g}$ of calcitriol on d 0 , followed by another dose of $50 \mu \mathrm{g}$ on d 6 . Blood was sampled by puncture of the coccygeal vessels into lithium-heparinized evacuated tubes (Vacutainer; Becton Dickinson) immediately before administration of treatment, and at $4,8,12$, and 24 h daily until d 15 , and at $12 \mathrm{~h}$ after the second administration on $\mathrm{d} 6$. Tubes were placed in ice and transported to the laboratory within $30 \mathrm{~min}$ and centrifuged for $15 \mathrm{~min}$ at 2,500 $\times \mathrm{g}$ for plasma separation. Plasma samples were transferred to microtubes and stored frozen at $-20^{\circ} \mathrm{C}$ until analysis. Plasma samples were analyzed for concentrations of tCa, tMg, and calcitriol as described in experiment 2 .

\section{Experiment 2}

Experimental Design, Cows, Housing, and Treatments. The experiment was a randomized complete block design. Holstein cows were blocked by parity as lactation 2 or greater than 2 , and sequence of calving. Within each block, cows were assigned randomly to 1 of 2 treatments within $6 \mathrm{~h}$ of calving. All treatments were performed before colostrum milking. The chosen dose of calcitriol was based on the results of experiment 1. Treatments were administered by subcutaneous injection in the ischioanal fossa of vehicle only (control, 25 cows) or a solution containing $300 \mu \mathrm{g}$ of calcitriol (CAL, 25 cows). Calcitriol-treated cows received $6 \mathrm{~mL}$ of the $95 \%$ oleaginous solution, with calcitriol at a concentration of $50 \mu \mathrm{g} / \mathrm{mL}$; control cows received $6 \mathrm{~mL}$ of the control solution that did not contain the calcitriol crystalline powder.

Prepartum cows were housed in a freestall barn in the last 4 wk of gestation. Cows were observed 4 times daily at 6 -h intervals for signs of parturition to ensure that experimental enrollment occurred within the first $6 \mathrm{~h}$ after calving. Upon calving and experimental enrollment, postpartum cows were housed in a free-stall barn equipped with individual feeding gates (American Calan Inc., Northwood, NH) that were assigned ran- 
domly to each cow. Individual cow DMI was measured for the first 36 DIM.

Diets, Feeding, and Analysis of Dietary Ingredients. Prepartum cows were fed once daily, and postpartum cows were fed twice daily. Diets were fed as a TMR for ad libitum intake. In the postpartum period, the amounts of diets offered and refused were measured daily for each cow to calculate DMI. Prepartum cows received a diet formulated to have a negative DCAD to minimize the degree of hypocalcemia. Spot urine samples were collected weekly from cows fed the prepartum diet, and $\mathrm{pH}$ was measured to ensure that the diet resulted in mild metabolic acidosis. The group mean weekly urine $\mathrm{pH}$ ranged between 5.9 and 6.6. Postpartum cows received the same TMR, with a positive $\mathrm{DCAD}$, to meet or exceed the nutrient requirements for a lactating Holstein cow weighing $650 \mathrm{~kg}$ and producing $40 \mathrm{~kg}$ of $3.5 \% \mathrm{FCM} / \mathrm{d}$ with an average intake of $23 \mathrm{~kg}$ of DM in the first 36 DIM (NRC, 2001).

Individual forages, brewer's grains and concentrate mixtures were sampled weekly and dried in an airforced oven at $55^{\circ} \mathrm{C}$ for $48 \mathrm{~h}$, and moisture loss was recorded. Individual dried samples were ground to pass through a 1.0-mm mesh screen. Samples were composited monthly and analyzed for $\mathrm{OM}\left(512^{\circ} \mathrm{C}\right.$ for 8 h); NDF using a heat stable $\alpha$-amylase followed by sequential ADF analysis with the Ankom Fiber Analyzer system (Ankom Technology, Macedon, NY); N using an automated quantitative combustion digestion method; starch using an enzymatic digestion method and subsequent quantification of glucose; fat by acid hydrolysis; and minerals using inductively coupled plasma mass spectrometry at a commercial laboratory (Dairyland Laboratories Inc., Arcadia, WI). Table 1 depicts the ingredient composition and nutrient content of TMR fed in the pre- and postpartum periods.

Measurements of Yields of Milk and Milk Components. Cows were milked twice daily at 1000 and $2200 \mathrm{~h}$, and milk production was recorded automatically using milk meters (AfiFlo; S.A.E. Afikim, Israel). The yield and composition of colostrum and milk from the second milking were analyzed separately from other milk measurements.

Milk samples were collected at every milking for the first 5 DIM, after which milk was sampled in 2 consecutive milkings twice a week until 36 DIM. Samples were submitted to the Southeast DHI laboratory in Belleview, Florida, and analyzed for concentrations of fat, true protein, lactose, and somatic cells. The yields of $3.5 \%$ FCM and ECM were calculated as follows: FCM $=[(0.4324 \times \mathrm{kg}$ of milk $)+(16.218 \times \mathrm{kg}$ of fat $)] ; \mathrm{ECM}$ $=[(0.3246 \times \mathrm{kg}$ of milk $)+(12.86 \times \mathrm{kg}$ of fat $)+(7.04$ $\times \mathrm{kg}$ of protein)]. The SCS was calculated according to the following formula: $\mathrm{SCS}=\log _{10}(\mathrm{SCC} / 12.5) / \log _{10} 2$.
The contents of tCa and tMg in colostrum and milk from the second milking postpartum were also analyzed. Frozen samples of colostrum and milk were thawed, thoroughly homogenized, and an aliquot of $2.5 \mathrm{~mL}$ pipetted into $50-\mathrm{mL}$ tubes. Then, $25 \mathrm{~mL}$ of $24 \%$ trichloroacetic acid and $22.5 \mathrm{~mL}$ of deionized water were added to each tube. Samples were agitated and homogenized every $5 \mathrm{~min}$ for $30 \mathrm{~min}$. The solution was filtered and a 5 -mL aliquot of the filtrate was transferred to another 50 -mL tube. After that, $1 \mathrm{~mL}$ of lanthanum chloride $5 \%$ and $44 \mathrm{~mL}$ of deionized water were added to each tube to result in a $50-\mathrm{mL}$ solution. Samples were analyzed by atomic absorption using a spectrophotometer (AAnalyst 200; Perkin-Elmer Inc., Waltham, MA) equipped with Ca- and Mg-specific hollow cathode lamps. The amounts of tCa and $\mathrm{tMg}$ secreted in the first day postpartum were calculated based on yields of colostrum and milk from second milking and the respective concentrations of tCa and $\mathrm{tMg}$.

$\boldsymbol{B} \boldsymbol{W}$ and $\boldsymbol{B} \boldsymbol{C S}$. Cows were weighed twice per day after each milking as they left the milking parlor, using a walk-through scale (AfiWeigh; S.A.E. Afikim). Cows' BW were averaged for each day for the first 36 DIM. Twice a week, cows' BCS was evaluated by the same evaluator using a 5 -point scale $(1=$ emaciated to $5=$ obese), divided into 0.25 points according to Ferguson et al. (1994) as depicted in the Elanco BCS chart (Elanco Animal Health, 2009).

Blood Minerals, Metabolites, and Hormones. Blood was sampled by puncture of the coccygeal vessels into lithium-heparinized evacuated tubes (Vacutainer; Becton Dickinson) immediately before administration of treatments, $12 \mathrm{~h}$ after, and again at 1, 2, 3, 5, 7, 9, 12, and 15 DIM. Tubes were placed on ice, transported to the laboratory within $30 \mathrm{~min}$, and centrifuged for $15 \mathrm{~min}$ at $2,500 \times g$ for plasma separation. Plasma samples were transferred to microtubes and stored frozen at $-20^{\circ} \mathrm{C}$ until analysis. Blood was also sampled immediately before administration of treatments, $12 \mathrm{~h}$ later, and at 1, 2, 3, and 5 DIM, and analyzed for concentrations of $\mathrm{iCa}, \mathrm{Na}^{+}, \mathrm{K}^{+}$, and glucose using a hand-held biochemical analyzer (i-Stat; Abbott Laboratories, Princeton, NJ).

Concentrations of calcitriol in plasma were analyzed by ELISA $\left[1 \alpha, 25(\mathrm{OH})_{2}\right.$ Vitamin D ELISA; IBL-America, Minneapolis, MN] according to the manufacturer's instructions (http://www.ibl-america.com/pdf/elisa/ KAP1921.pdf). The intra- and interassay CV were 8.0 and $11.6 \%$, respectively. Concentrations of calcidiol in plasma were analyzed by ELISA [25(OH) Vitamin D ELISA; DRG Instruments GmbH, Marburg, Germany] according to the manufacturer's instructions (http:// www.drg-diagnostics.de/files/eia-5396_ifu--25-oh-vitamin-d_2016-06-07_endeit.pdf), except that a custom 
Table 1. Ingredient composition and nutrient content of pre- and postpartum diets in experiment 2

\begin{tabular}{|c|c|c|}
\hline \multirow[b]{2}{*}{ Item } & \multicolumn{2}{|c|}{ Diet $^{1}$} \\
\hline & Prepartum & Postpartum \\
\hline \multicolumn{3}{|l|}{ Ingredients, $\%$ of DM } \\
\hline Corn silage & 50.0 & 21.6 \\
\hline Bermuda grass hay & 17.0 & - \\
\hline Alfalfa hay & - & 23.9 \\
\hline Brewers grains, wet & 20.0 & 12.0 \\
\hline Corn, finely ground & - & 19.7 \\
\hline Soybean hulls & 3.4 & - \\
\hline Citrus pulp, dry & - & 5.9 \\
\hline Whole cottonseed & - & 4.8 \\
\hline Soybean meal, solvent extracted & - & 5.7 \\
\hline Saturated free fatty acids ${ }^{2}$ & - & 1.1 \\
\hline Prepartum mineral and vitamin supplement ${ }^{3}$ & 4.0 & - \\
\hline Acidogenic product ${ }^{4}$ & 5.0 & - \\
\hline Mineral-vitamin protein mix $^{5}$ & - & 4.8 \\
\hline Mycotoxin binder ${ }^{6}$ & 0.6 & 0.5 \\
\hline \multicolumn{3}{|l|}{ Nutrient content, DM basis } \\
\hline $\mathrm{NE}_{\mathrm{L}},{ }^{7} \mathrm{Mcal} / \mathrm{kg}$ & 1.53 & 1.67 \\
\hline $\mathrm{OM}, \%$ & $93.0 \pm 0.3$ & $90.9 \pm 0.5$ \\
\hline $\mathrm{CP}, \%$ & $13.6 \pm 0.3$ & $18.5 \pm 0.8$ \\
\hline NDF, \% & $44.1 \pm 2.3$ & $29.8 \pm 1.1$ \\
\hline Forage NDF, \% & $30.3 \pm 2.3$ & $17.6 \pm 0.8$ \\
\hline $\mathrm{ADF}, \%$ & $26.5 \pm 2.0$ & $19.3 \pm 0.5$ \\
\hline $\mathrm{NFC}^{8} \%$ & $34.1 \pm 1.9$ & $39.9 \pm 0.5$ \\
\hline Starch, \% & $20.0 \pm 3.0$ & $23.8 \pm 0.8$ \\
\hline Ether extract, \% & $4.5 \pm 0.1$ & $5.3 \pm 0.3$ \\
\hline $\mathrm{Ca}, \%$ & $0.76 \pm 0.02$ & $0.87 \pm 0.05$ \\
\hline $\mathrm{P}, \%$ & $0.32 \pm 0.01$ & $0.35 \pm 0.01$ \\
\hline $\mathrm{Mg}, \%$ & $0.59 \pm 0.03$ & $0.45 \pm 0.03$ \\
\hline $\mathrm{K}, \%$ & $0.95 \pm 0.11$ & $1.62 \pm 0.07$ \\
\hline S, $\%$ & $0.32 \pm 0.02$ & $0.23 \pm 0.02$ \\
\hline $\mathrm{Na}, \%$ & $0.05 \pm 0.02$ & $0.54 \pm 0.01$ \\
\hline $\mathrm{Cl}, \%$ & $0.68 \pm 0.04$ & $0.59 \pm 0.06$ \\
\hline $\mathrm{DCAD},{ }^{9} \mathrm{mEq} / \mathrm{kg}$ & $-123 \pm 32$ & $364 \pm 41$ \\
\hline
\end{tabular}

${ }^{1}$ Prepartum diet was fed from $255 \mathrm{~d}$ of gestation to calving and postpartum diet from calving to 36 DIM.

${ }^{2}$ Energy Booster Mag (Milk Specialties, Eden Prairie, MN).

${ }^{3}$ Contents (DM basis): $64.1 \%$ corn gluten feed; $8.2 \%$ calcium carbonate; $15.7 \%$ magnesium sulfate hepathydrate; $6.0 \%$ magnesium oxide; $2.3 \%$ sodium chloride; $0.42 \%$ Sel-Plex 2000 (Alltech Biotechnology, Nicholasville, KY); $0.27 \%$ Intellibond Vital 4 (Micronutrients, Indianapolis, IN); $0.002 \%$ ethylenediamine dihydriodide; $0.66 \%$ of a premix containing vitamins A, D and E; 0.37\% Rumensin 90 (Elanco Animal Health, Greenfield, IN); and $2.0 \%$ ClariFly Larvicide (Central Life Sciences, Schaumburg, IL). Each kilogram contained 13.6\% CP, $3.7 \%$ $\mathrm{Ca}, 0.7 \% \mathrm{P}, 5.5 \% \mathrm{Mg}, 0.9 \% \mathrm{~K}, 1.1 \% \mathrm{Na}, 1.6 \% \mathrm{Cl}, 2.6 \% \mathrm{~S}, 788 \mathrm{mg}$ of $\mathrm{Zn}, 180 \mathrm{mg}$ of Cu, $581 \mathrm{mg}$ of $\mathrm{Mn}, 9 \mathrm{mg}$ of Se, $4.4 \mathrm{mg}$ of Co, $16 \mathrm{mg}$ of I, 104,000 IU of vitamin A, 30,000 IU of vitamin D, 1,500 IU of vitamin E, and $800 \mathrm{mg}$ of monensin.

${ }^{4}$ SoyChlor (West Central Soy, Landus Cooperative, Ames, IA).

${ }^{5}$ Contents (DM basis): 19.4\% LysAAmet blood meal (Perdue Agribusiness, Salisbury, MD); 26.8\% sodium sesquicarbonate; 14.4\% DCAD Plus (Arm and Hammer Animal Nutrition, Trenton, NJ); 5.7\% potassium chloride; $13.2 \%$ calcium carbonate; $4.0 \%$ dicalcium phosphate; $7.7 \%$ magnesium oxide; $6.6 \%$ sodium chloride; $0.22 \%$ Intellibond Vital 4 (Micronutrients); 0.39\% Sel-Plex 2000 (Alltech Biotechnology); 0.0015\% ethylenediamine dihydriodide; $0.32 \%$ of a premix containing vitamins A, D and E; $0.11 \%$ biotin $2 \% ; 0.22 \%$ Rumensin 90 (Elanco Animal Health); and 1.0\% ClariFly Larvicide (Central Life Sciences). Each kilogram contained 17.2\% CP, $6.2 \% \mathrm{Ca}, 0.9 \% \mathrm{P}, 4.5 \% \mathrm{Mg}, 10.4 \% \mathrm{~K}, 11.5 \% \mathrm{Na}, 7.2 \% \mathrm{Cl}, 0.2 \% \mathrm{~S}, 605 \mathrm{mg}$ of $\mathrm{Zn}, 143 \mathrm{mg}$ of Cu, $490 \mathrm{mg}$ of $\mathrm{Mn}, 8 \mathrm{mg}$ of Se, $4.4 \mathrm{mg}$ of Co, $12 \mathrm{mg}$ of I, 160,000 IU of vitamin A, 28,000 IU of vitamin D, 1,500 IU of vitamin $\mathrm{E}$, and $460 \mathrm{mg}$ of monensin.

${ }^{6}$ NovaSilPlus (BASF, Florham Park, NJ).

${ }^{7}$ Calculated using the NRC (2001) guidelines according to the chemical composition of the dietary ingredients and adjusted for 11 and $20 \mathrm{~kg}$ of DM intake for the pre- and postpartum periods, respectively.

${ }^{8}$ Calculated as follows: NFC $=\mathrm{DM}-($ ash $+\mathrm{CP}+$ ether extract $+\mathrm{NDF}-\mathrm{NDF}$ insoluble CP $)$.

${ }^{9}$ Calculated as follows: $\mathrm{DCAD}=[(\mathrm{mEq}$ of $\mathrm{K})+(\mathrm{mEq} \mathrm{Na})]-[(\mathrm{mEq}$ of $\mathrm{Cl})+(\mathrm{mEq}$ of $\mathrm{S})]$. 
standard prepared in bovine serum was used in place of the standard provided with the kit, as previously described (Nelson et al., 2016). The intra- and interassay CV were 6.1 and $11.2 \%$, respectively. Concentrations of 24,25-dihydroxyvitamin $\mathrm{D}_{2}$ and 24,25-dihydroxyvitamin $\mathrm{D}_{3}$ were analyzed by liquid chromatography-mass spectrometry by Heartland Assays (Ames, IA).

Concentrations of $\mathrm{tCa}$ and $\mathrm{tMg}$ in plasma were analyzed by atomic absorption (AAnalyst 200; PerkinElmer Inc.) as previously described (Martinez et al., 2012). Intra- and interassay CV were 2.1 and $5.9 \%$ for tCa, and 4.2 and $4.7 \%$ for $\mathrm{tMg}$, respectively. Concentrations of $\mathrm{tP}$ were quantified in plasma using the molybdenum blue method (Quinlan and DeSesa, 1955). The intra- and interassay CV were 3.3 and $4.1 \%$, respectively. Subclinical hypocalcemia was defined based on concentrations of tCa in plasma below $2.125 \mathrm{mM}$ (Martinez et al., 2016).

Concentrations of nonesterified fatty acids (NEFA; NEFA-C kit, Wako Diagnostics Inc., Mountain View, $\mathrm{CA}$ ) and BHB (Wako Autokit 3-HBt; Wako Diagnostics Inc.) in plasma were analyzed by colorimetric methods. The intra- and interassay $\mathrm{CV}$ were 2.5 and $3.4 \%$ for NEFA and 4.3 and $7.0 \%$ for BHB, respectively. Concentrations of urea $\mathrm{N}$ and glucose in plasma were determined by colorimetric continuous flow analysis (Autoanalyzer II; SEAL Analytical, Segensworth, Fareham Hampshire, UK) using a modification of the method described by Gochman and Schmitz (1972).

Concentrations of serotonin in plasma were analyzed by ELISA (Serotonin EIA kit; Enzo Life Sciences, Farmingdale, NY) according to the manufacturer's instructions (http://www.enzolifesciences.com/ADI900-175/serotonin-elisa-kit/). The intra- and interassay CV were 10.2 and $21.2 \%$, respectively. Intact PTH was determined using an ELISA assay (Bovine Intact PTH ELISA Kit; Immutopics Inc., San Clemente, CA) according to the manufacturer's instructions (http:// www.immutopics.com/pdf/directional-inserts/60-3500. pdf). The intra- and interassay CV were 7.1 and $15.7 \%$, respectively. The bone resorption marker C-telopeptide of type I collagen (CTX-1) was measured in plasma by ELISA (Bovine CTX-1 ELISA Kit, NeoScientific, London, UK), and the intra- and interassay CV were 6.2 and $14.1 \%$, respectively.

Urinary Excretion of Minerals and Creatinine. Urine samples were collected at 1, 2, 3, 5, and 7 DIM. The perineal area was massaged until a clean and copious stream of urine was obtained. Samples were frozen at $-20^{\circ} \mathrm{C}$ for later analyses of concentrations of creatinine, tCa, and $\mathrm{tMg}$. Samples were analyzed for creatinine using a commercial colorimetric method (Creatinine Urinary Detection Kit; Arbor Assays, Ann Arbor, MI). Samples were diluted 1 to 400 with $0.5 \%$ lanthanum chloride, and concentrations of $\mathrm{tCa}$ and $\mathrm{tMg}$ were analyzed by atomic absorption using a spectrophotometer equipped with Ca- and $\mathrm{Mg}$-specific hollow cathode lamps (AAnalyst 200; Perkin-Elmer Inc.). The intra- and interassay CV for creatinine were 2.2 and $8.6 \%$, respectively. Urinary tCa and $\mathrm{tMg}$ assays were performed as a single run, and the intra-assay $\mathrm{CV}$ were 5.4 and $1.3 \%$, respectively. Creatinine was used as a marker to estimate daily urinary volume based on the constant excretion of $29 \mathrm{mg}$ of creatinine per $\mathrm{kg}$ of BW per day (Valadares et al., 1999). The estimate of daily urinary volume was calculated as: $\mathrm{BW} \mathrm{kg} \times 29 /$ urinary concentrations of creatinine $\mathrm{mg} / \mathrm{L}$ (e.g., $680 \mathrm{~kg} \times$ $29 / 600 \mathrm{mg} / \mathrm{L}$ urine $=32.86 \mathrm{~L}$ of urine/day). Daily urinary excretions of tCa and $\mathrm{tMg}$ were calculated based on the urinary volume and the concentrations of those minerals in the urine samples.

Complete Blood Cell Counts and Neutrophil Function. Blood was sampled by puncture of the coccygeal blood vessels into evacuated tubes (Vacutainer; Becton Dickinson) containing either lithium heparin or $\mathrm{K}_{2}$ EDTA at 2, 4, and 6 DIM. Samples were kept at room temperature, protected from light, and transported to the laboratory within $2 \mathrm{~h}$ of collection. Samples collected with $\mathrm{K}_{2}$ EDTA were used for analysis of differential blood cell count using an automated hematology analyzer (ProCyte Dx Hematology Analyzer; Idexx Laboratories, Westbrook, ME). Samples collected with heparin were used for flow cytometric assays to quantify neutrophil phagocytosis and oxidative burst.

Function of neutrophils in vitro was assayed by dual color flow cytometry according to Martinez et al. (2012). Escherichia coli 08:H19 strain KCJ852 isolated from a cow with metritis was labeled with propidium iodide and used to quantify neutrophil phagocytosis and intracellular killing. Briefly, $100 \mu \mathrm{L}$ of blood was pipetted into 4 tubes, and $10 \mu \mathrm{L}$ of $5 \mu M$ dihydrorhodamine 123 was added to each tube. Tube 1 was used as a negative control, containing only blood and $5 \mu M$ dihydrorhodamine 123. Phorbol 12-myristate 13-acetate was added to tube 2 to induce oxidative burst activity in neutrophils as a positive control. In tubes 3 and 4, propidium iodide-labeled $E$. coli were added to the tubes to achieve a bacterium-to-neutrophil ratio of 40 to 1 . The samples were analyzed using an Accuri C6 digital analyzer flow cytometer (BD Biosciences, San Jose, CA). Forward and side scatter gating of granulocytes resulted in more than $90 \%$ neutrophils selected in the granulocyte cell population evaluated. Data acquisitions from at least 10,000 cells per sample were analyzed using Flowjo software (version 10.0.8; Tree Star Inc., Ashland, OR). Blood from a second-lactation pregnant Holstein cow in mid-lactation was used in every neutrophil assay as a reference throughout the experiment, and the results 
for neutrophil function were expressed relative to the reference cow. The parameters analyzed were percentage of neutrophils that phagocytized bacteria, and the percentage of neutrophils with phagocytosis-induced oxidative burst. Furthermore, histogram analysis for mean fluorescence intensity (MFI) of oxidized dihydrorhodamine and propidium iodide-labeled bacteria were used to estimate the neutrophil mean oxidative burst intensity as an indication of the intensity of reactive oxygen species produced per neutrophil, and neutrophil mean phagocytic activity as an indication of the number of bacteria phagocytized per neutrophil, respectively.

\section{Statistical Analysis}

Continuous data were evaluated for distribution of the residuals and homogeneity of variance after model fitting. Data with violation of the assumptions of normality were subjected to Box-Cox transformation using the TRANSREG procedure of SAS (SAS/STAT version 9.4; SAS Institute Inc., Cary, NC) before final statistical analyses. When data were transformed, the least squares means were back-transformed and standard error of the mean calculated (Jørgensen and Pedersen, 1998).

In experiment 1 , the effects of 0,200 , or $300 \mu \mathrm{g}$ of calcitriol on plasma concentrations of $\mathrm{tCa}, \mathrm{tMg}$, and tP were analyzed using the MIXED procedure of SAS. The statistical models included the fixed effects of dose (0 vs. 200 vs. $300 \mu \mathrm{g}$ ), day after treatment, and the interaction between dose and day after treatment, and the random effect of cow nested within dose. Measurements taken immediately before dosing were used as covariates in the statistical models. When a single dose was used, means and standard deviation were calculated using the MEANS procedure of SAS.

In experiment 2, continuous data were analyzed using the MIXED procedure of SAS. The statistical models included the fixed effects of treatment (control vs. CAL), day postpartum, and the interaction between treatment and day postpartum, and the random effects of block and of cows nested within treatment and block. Measurements taken on d 0, before treatment administration, were used as covariates for adjustment during analyses. The covariance structure with the smallest Akaike's information criterion was chosen, and most analyses used the first-order autoregressive structure for equally spaced measurements or spatial power for unequally spaced measurements. The Kenward-Roger method was used to obtain the approximate denominator degrees of freedom. When the F-test for an interaction between treatment and day postpartum was sig- nificant, means were then portioned using the SLICE command in SAS.

The incidence and daily prevalence of subclinical hypocalcemia were analyzed by logistic regression using the GLIMMIX procedure of SAS fitting a binary distribution. For incidence of subclinical hypocalcemia, the model included the fixed effect of treatment and the random effect of block. For the daily prevalence of subclinical hypocalcemia, the model included the fixed effects of treatment, day, interaction between treatment and day, and the random effects of block and cow nested within treatment and block.

Treatment differences with $P \leq 0.05$ were considered significant, whereas tendencies for differences were reported if $0.05<P \leq 0.10$.

\section{RESULTS}

\section{Experiment 1}

Treatment with calcitriol administered as a single dose of either 200 or $300 \mu \mathrm{g}$ increased $(P<0.05)$ the concentrations of plasma tCa within $24 \mathrm{~h}$ of treatment, and they remained elevated for the first $3 \mathrm{~d}$ after treatment compared with cows that received $0 \mu \mathrm{g}$ of calcitriol (Figure 1A). Similar to concentrations of tCa, treatment with 200 or $300 \mu \mathrm{g}$ of calcitriol increased $(P$ $<0.05)$ the concentrations of tP in plasma in the first $3 \mathrm{~d}$ after treatment compared with cows that received 0 $\mu \mathrm{g}$ of calcitriol (Figure 1B). Concentrations of tCa and tP in plasma did not differ between treatments beyond the third day after treatment with calcitriol. Treatment with $200 \mu \mathrm{g}$ or $300 \mu \mathrm{g}$ of calcitriol reduced $(P<0.05)$ the concentrations of $\mathrm{tMg}$ in plasma in the first $4 \mathrm{~d}$ after treatment compared with cows that received $0 \mu \mathrm{g}$ of calcitriol (Figure 1C), with no differences between treatments after 5 DIM.

Administration of $300 \mu \mathrm{g}$ of calcitriol to late-lactation dairy cows increased plasma calcitriol from $22.5 \pm 6.5$ to $488.9 \pm 31.4 \mathrm{pg} / \mathrm{mL}$ in $24 \mathrm{~h}$ (Figure 1D). Furthermore, the second administration of $50 \mu \mathrm{g}$ calcitriol on d 6 increased plasma calcitriol from $10.7 \pm 1.9 \mathrm{pg} / \mathrm{mL}$ immediately before administration to $50.8 \pm 7.4$ in 12 h. Concentrations of tCa in plasma increased from 2.52 \pm 0.14 to $3.02 \pm 0.24 \mathrm{~m} M$ during the first $48 \mathrm{~h}$ after treatment with $300 \mu \mathrm{g}$ of calcitriol (Figure 1E), and increased from $2.92 \pm 0.24$ to $3.08 \pm 0.15 \mathrm{~m} M$ during the first $24 \mathrm{~h}$ after the second treatment with $50 \mu \mathrm{g}$ of calcitriol on d 6. From d 7 to d 15 after the first treatment, concentration of tCa in plasma decreased from $3.08 \pm 0.15$ to $2.41 \pm 0.13 \mathrm{~m} M$, and remained in the normocalcemic range. Concentrations of tMg in plasma decreased from $0.97 \pm 0.12$ to $0.81 \pm 0.06 \mathrm{mM}$ 

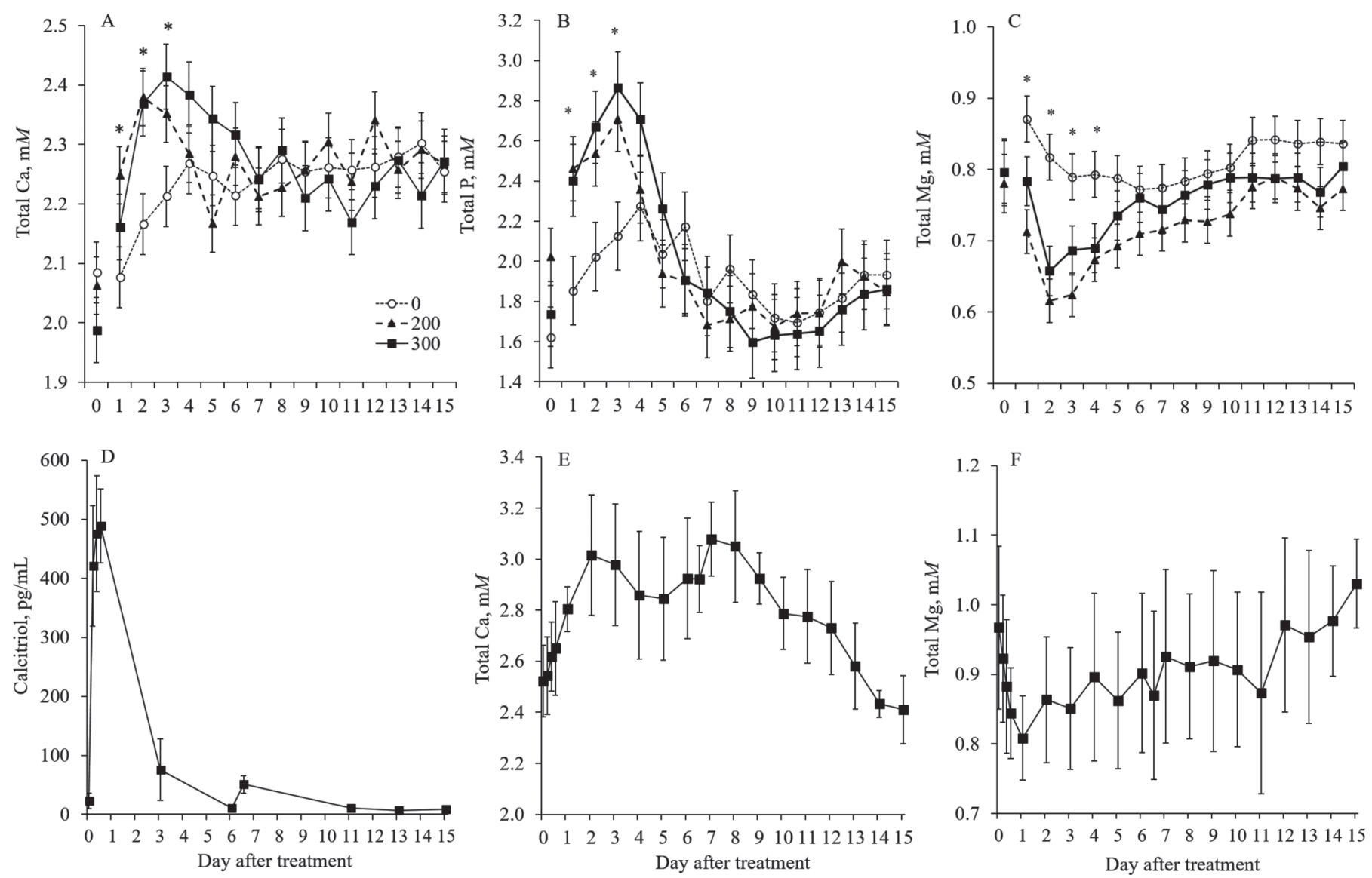

Figure 1. Concentrations of (A) total Ca, (B) total P, and (C) total $\mathrm{Mg}$ in plasma of cows after dosing 0, 200, or 300 $\mu \mathrm{g}$ of calcitriol, and concentrations of (D) calcitriol, (E) total Ca, and (F) total Mg in plasma of dairy cows after dosing $300 \mu \mathrm{g}$ of calcitriol on d 0 and another $50 \mu \mathrm{g}$ on d 6 in experiment 1. In panels A to C, values represent LSM and SEM. In panels D to F, values represent means \pm SD. (A) Effects of dose $(P=0.65)$, day $(P<0.001)$, and interaction between dose and day $(P=0.02)$; (B) effects of dose $(P<0.01)$, day $(P<0.001)$, and interaction between dose and day $(P=0.78)$; $(\mathrm{C})$ effects of dose $(P=0.82)$, day $(P<0.001)$, and interaction between dose and day $(P=0.19)$. Within a day, ${ }^{*}$ denotes a difference between treatments $(P<0.05)$.

during the first $24 \mathrm{~h}$ after treatment with $300 \mu \mathrm{g}$ of calcitriol (Figure 1F). The second treatment with $50 \mu \mathrm{g}$ of calcitriol $6 \mathrm{~d}$ later had minor effects on plasma tMg concentrations.

Collectively, these results showed a sustained increase in plasma tCa in dairy cows for at least $3 \mathrm{~d}$ after administration of $300 \mu \mathrm{g}$ of calcitriol, with no apparent signs of subsequent hypocalcemia. We judged that the second dose of $50 \mu \mathrm{g}$ of calcitriol would not be necessary, because tCa concentrations remained in the normocalcemic range. Therefore, $300 \mu \mathrm{g}$ of calcitriol as a single treatment was chosen for experiment 2 .

\section{Experiment 2}

Concentrations of Vitamin $D$ Metabolites in Plasma. The CAL treatment increased $(P<0.01)$ plasma calcitriol concentrations compared with that of controls starting $12 \mathrm{~h}$ after treatment, and differences were observed until 3 DIM, after which the concentrations did not differ between treatments (Figure 2A). Concentrations of calcidiol in plasma did not differ between treatments, and averaged $55.4 \pm 2.5 \mathrm{ng} / \mathrm{mL}$ for controls and $56.1 \pm 2.5 \mathrm{ng} / \mathrm{mL}$ for CAL cows in the first 3 DIM (Figure 2B). Concentrations of 24,25-dihydroxyvitamin $\mathrm{D}_{2}$ in plasma did not differ between CAL cows and control cows (Figure 2C). On the other hand, treatment with CAL increased $(P<0.01)$ concentrations of 24, 25-dihydroxyvitamin $\mathrm{D}_{3}$ in plasma; concentrations averaged $3.24 \pm 0.32 \mathrm{ng} / \mathrm{mL}$ for control cows and $4.09 \pm 0.32 \mathrm{ng} / \mathrm{mL}$ for CAL-treated cows (Figure 2D).

Concentrations of Minerals in Whole Blood and Plasma and Prevalence of Subclinical Hypocalcemia. Treatment with CAL within 6 h of calving increased $(P<0.01)$ the concentrations of $\mathrm{iCa}$ in whole blood compared with control cows starting $24 \mathrm{~h}$ after treatment, and differences were observed until 3 DIM, 

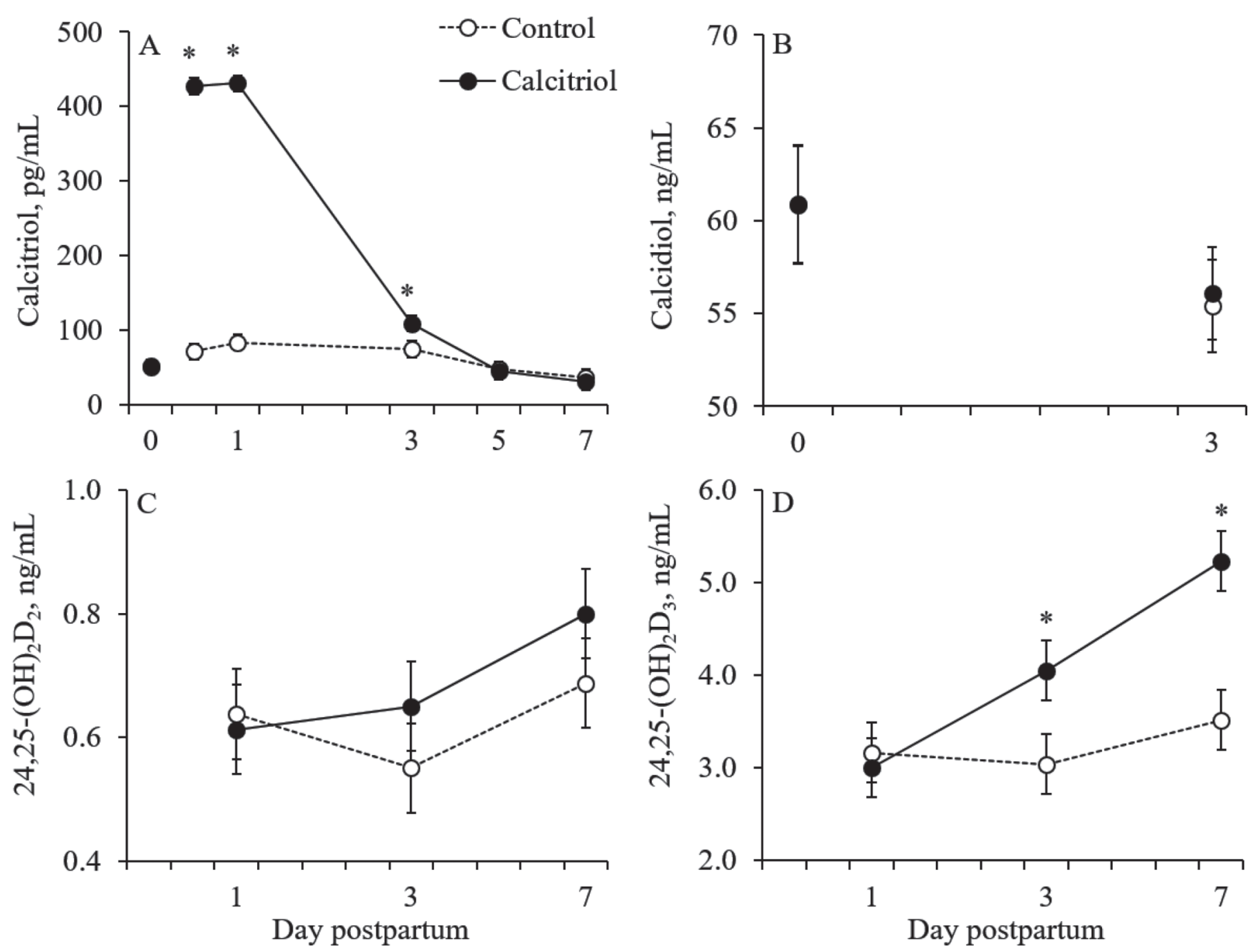

Figure 2. Concentrations of (A) calcitriol, (B) calcidiol, (C) 24,25-dihydroxyvitamin $\mathrm{D}_{2}$, and (D) 24,25-dihydroxyvitamin $\mathrm{D}_{3}$ in plasma of dairy cows receiving an injection of placebo (control) or $300 \mu \mathrm{g}$ of calcitriol in experiment 2 . (A) Effects of treatment $(P<0.01)$, day $(P<$ $0.0001)$, and interaction between treatment and day $(P<0.0001)$; (B) effects of treatment $(P=0.84) ;(\mathrm{C})$ effects of treatment $(P=0.45)$, day $(P$ $=0.04)$, and interaction between treatment and day $(P=0.44)$; (D) effects of treatment $(P<0.0001)$, day $(P=0.11)$, and interaction between treatment and day $(P=0.30)$. Within a day, ${ }^{*}$ denotes difference between treatments $(P<0.05)$. Error bars denote SEM.

after which the concentrations did not differ between treatments (Figure 3A). Concentrations of iCa in whole blood averaged $1.08 \pm 0.03$ and $1.20 \pm 0.03 \mathrm{mM}$ for control and CAL, respectively, in the first 5 DIM. Similar to iCa, CAL increased $(P<0.01)$ the concentrations of tCa in plasma compared with controls $24 \mathrm{~h}$ after treatment, and this increment lasted until 5 DIM (Figure 3B). In the first 5 DIM, concentrations of tCa averaged $2.12 \pm 0.04 \mathrm{~m} M$ for control cows and $2.44 \pm$ $0.04 \mathrm{~m} M$ for CAL cows; however, treatment with CAL resulted in smaller $(P<0.05)$ concentrations of tCa in plasma between 9 and 15 DIM compared with that in control cows, although cows in both treatments had mean tCa concentrations in plasma within the normocalcemic range during this period.
Calcitriol reduced $(P<0.05)$ the prevalence of subclinical hypocalcemia in the first 3 DIM compared with controls (Figure 4), and the daily prevalence rate in the first 3 DIM averaged 56.6 and $6.8 \%$ for control cows and CAL-treated cows, respectively. The daily prevalence of subclinical hypocalcemia did not differ between treatments on d 5, 7, and 15 postpartum, but it was greater for CAL-treated cows than for control cows on d 9 and 12 postpartum. At 9 and 12 DIM, the daily prevalence rate averaged 1.0 and $14.4 \%$ for control cows and CAL-treated cows, respectively.

Treatment with CAL increased $(P<0.01)$ the concentrations of tP in plasma compared with control cows starting $24 \mathrm{~h}$ after treatment, and the difference lasted until 7 DIM (Figure 3C), after which they normalized 

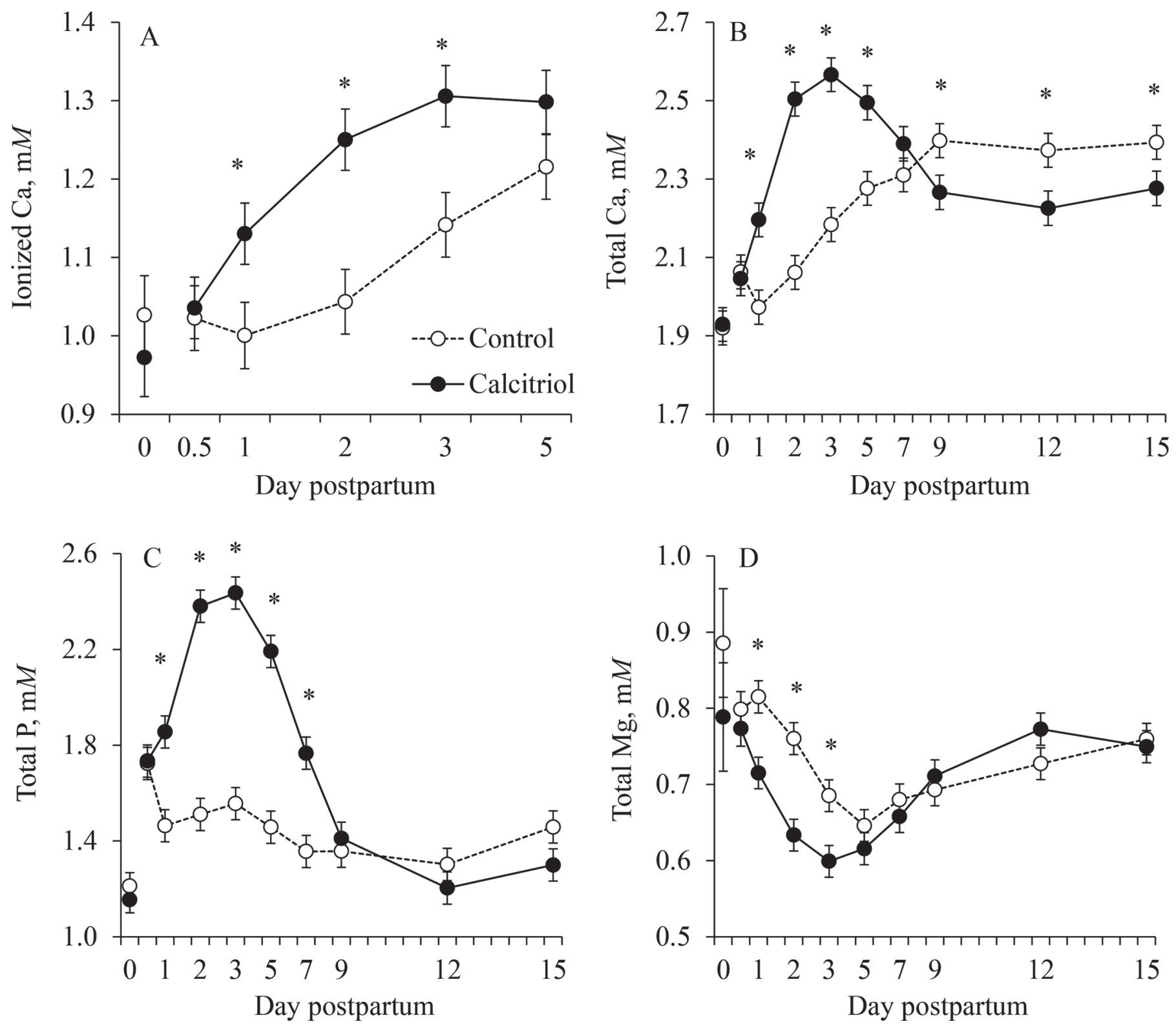

Figure 3. Concentrations of ionized $\mathrm{Ca}(\mathrm{iCa})$ in (A) whole blood, (B) total $\mathrm{Ca},(\mathrm{C})$ total $\mathrm{P}$, and (D) total $\mathrm{Mg}$ in plasma of dairy cows receiving an injection of placebo (control) or $300 \mu \mathrm{g}$ of calcitriol in experiment 2. (A) Effects of treatment $(P<0.001)$, day $(P<0.001)$, and interaction between treatment and day $(P=0.06)$; (B) effects of treatment $(P<0.01)$, day $(P<0.001)$, and interaction between treatment and day $(P<0.001)$; $(\mathrm{C})$ effects of treatment $(P<0.001)$, day $(P<0.001)$, and interaction between treatment and day $(P<0.001)$; $(\mathrm{D})$ effects of treatment $(P=0.07)$, day $(P<0.001)$, and interaction between treatment and day $(P<0.001)$. Within a day, ${ }^{*}$ denotes difference between treatments $(P<0.05)$. Error bars denote SEM.

and no longer differed between treatments. In the first 7 DIM, concentrations of $\mathrm{tP}$ in plasma averaged 1.47 $\pm 0.07 \mathrm{~m} M$ for control cows and $2.13 \pm 0.07 \mathrm{~m} M$ for CAL-treated cows. Concentrations of $\mathrm{tMg}$ decreased in both treatments after calving, but CAL induced a more accentuated decline $(P<0.01)$ in concentrations of tMg in plasma compared with controls from $24 \mathrm{~h}$ after treatment until 3 DIM (Figure 3D). In the first 3 DIM, concentrations of $\mathrm{tMg}$ in plasma averaged 0.75 $\pm 0.02 \mathrm{~m} M$ for control cows and $0.65 \pm 0.02 \mathrm{~m} M$ for CAL-treated cows. Concentrations of $\mathrm{tMg}$ in plasma increased after 5 DIM, and they did not differ between treatments after 3 DIM.

Concentrations of PTH, Serotonin, and Bone Resorption Marker in Plasma. Treatment with CAL reduced $(P=0.04)$ the concentrations of PTH in plasma compared with control cows starting $24 \mathrm{~h}$ after treatment, and differences were observed until 3 


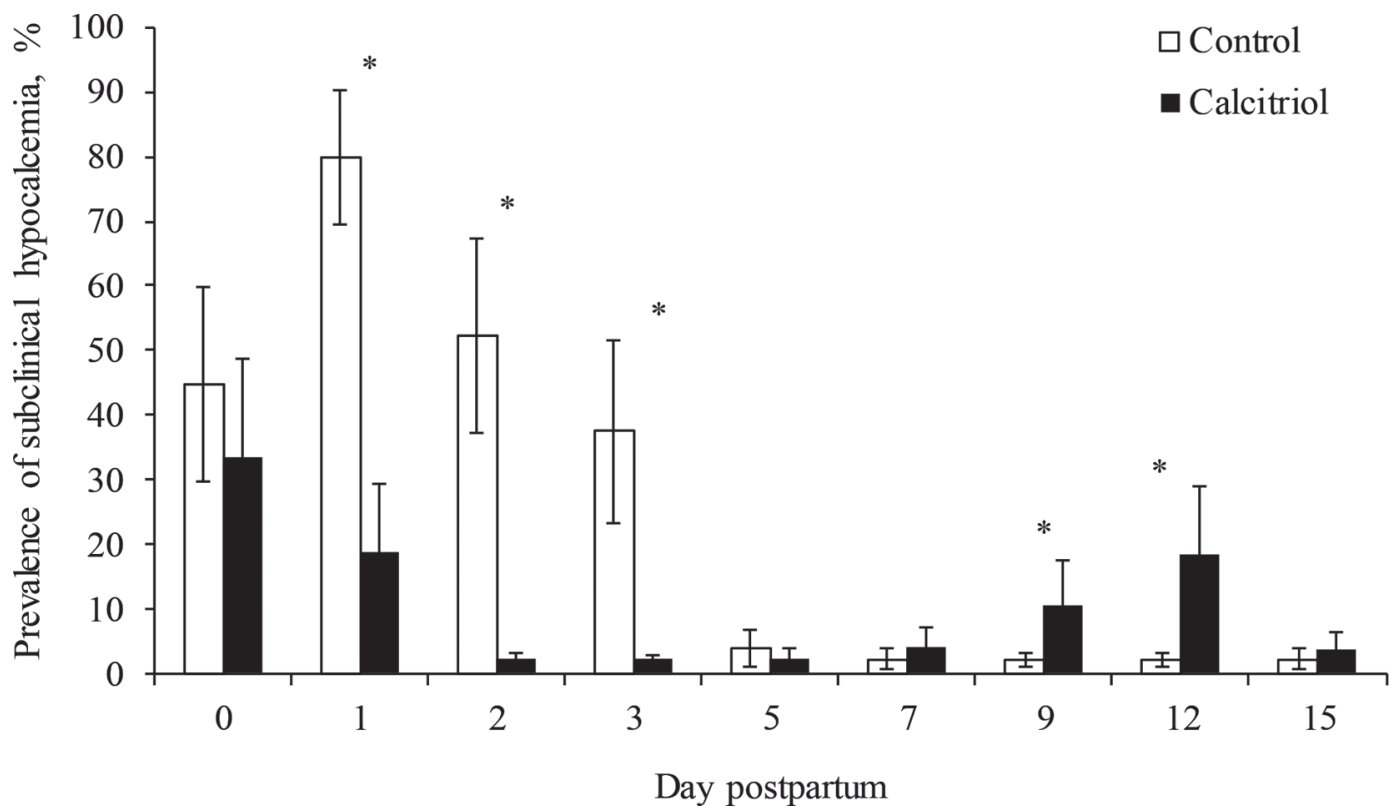

Figure 4. Daily prevalence of subclinical hypocalcemia $(\mathrm{SCH})$ in dairy cows receiving an injection of placebo (control) or $300 \mu \mathrm{g}$ of calcitriol in experiment 2. Subclinical hypocalcemia was defined as a plasma concentration of total Ca less than $2.125 \mathrm{~m} M$. Effects of treatment $(P=$ $0.28)$, day $(P<0.01)$, and interaction between treatment and day $(P<0.01)$. Within a day, ${ }^{*}$ denotes difference between treatments $(P<0.05)$. Error bars denote SEM.

DIM, after which the concentrations did not differ between treatments (Figure 5A). Concentrations of PTH in plasma averaged $475 \pm 48 \mathrm{pg} / \mathrm{mL}$ for control cows and $325 \pm 32 \mathrm{pg} / \mathrm{mL}$ for CAL-treated cows in the first 3 DIM. Treatment with CAL tended $(P=0.10)$ to increase concentrations of serotonin in plasma compared with control cows during the first 7 DIM, and averaged $1,350 \pm 162$ and $1,694 \pm 203 \mathrm{ng} / \mathrm{mL}$ for control cows and CAL-treated cows, respectively (Figure 5B). Furthermore, concentrations of the bone resorption marker CTX-1 increased $(P<0.05)$ in the first 7 DIM in both treatments, from a mean of $1.07 \mathrm{ng} / \mathrm{mL}$ at calving to
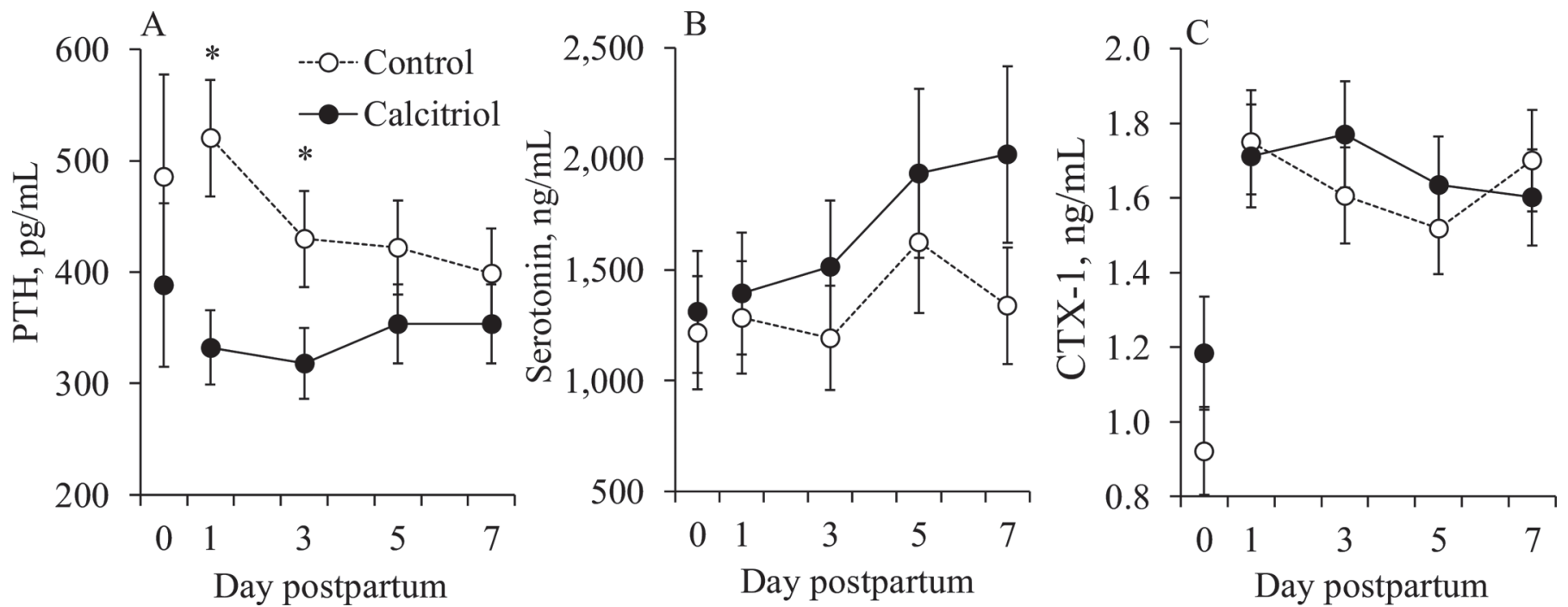

Figure 5. Concentrations of (A) parathyroid hormone (PTH), (B) serotonin, and (C) C-telopeptide of type I collagen (CTX-1) in plasma of dairy cows receiving an injection of placebo (control) or $300 \mu \mathrm{g}$ of calcitriol in experiment 2. (A) Effects of treatment $(P=0.04)$, day $(P<0.10)$, and interaction between treatment and day $(P=0.17) ;(\mathrm{B})$ effects of treatment $(P=0.10)$, day $(P=0.33)$, and interaction between treatment and day $(P=0.82) ;(\mathrm{C})$ effects of treatment $(P=0.75)$, day $(P=0.61)$, and interaction between treatment and day $(P=0.61)$. Within a day, $*$ denotes difference between treatments $(P<0.05)$. Error bars denote SEM. 
mean of $1.64 \pm 0.09$ and $1.68 \pm 0.09 \mathrm{ng} / \mathrm{mL}$ for control cows and CAL-treated cows in the first 7 DIM (Figure $5 \mathrm{C})$. Nevertheless, treatment did not affect concentrations of CTX-1 in plasma of dairy cows in the first week postpartum.

Composition and Yield of Colostrum and Milk in the Second Milking Postpartum. Treatment with CAL did not affect yields of colostrum or milk during the second milking postpartum, or their nutrient composition (Table 2). Cows produced an average $7.0 \mathrm{~kg}$ of colostrum and $6.7 \mathrm{~kg}$ of milk in the second postpartum milking. No differences were detected in the first day postpartum of net energy secreted into colostrum or milk. Likewise, concentrations of tCa and $\mathrm{tMg}$ in colostrum and milk from the second postpartum milking did not differ between treatments. Cows lost an average of $13.9 \mathrm{~g}$ of tCa and $2.9 \mathrm{~g}$ of $\mathrm{tMg}$ in colostrum, and 10.0 and $1.9 \mathrm{~g}$ of $\mathrm{tCa}$ and $\mathrm{tMg}$ in milk at the second milking, respectively. Collectively, cows lost $23.9 \mathrm{~g}$ of $\mathrm{tCa}$ and $4.8 \mathrm{~g}$ of $\mathrm{tMg}$ in the first day postpartum.

DMI, Milk Yield, BW, and BCS. DMI in the first 7 weeks postpartum did not differ between treatments (Table 3). Treatment with CAL did not affect yields of milk; milk components; concentrations of fat, true protein, and lactose in milk; or yields of $3.5 \% \mathrm{FCM}$ or ECM. Lack of changes in intake and production resulted in no differences in the caloric content of milk, energy output as milk, mean or change in BW and BCS, or energy balance. The SCS was not influenced by treatment.

Concentrations of Metabolites in Plasma. Treatment with CAL tended $(P=0.08)$ to increase the concentrations of $\mathrm{BHB}$ in plasma compared with controls (Figure 6A). Concentrations of BHB in plasma averaged $0.82 \pm 0.05$ and $0.97 \pm 0.06 \mathrm{~m} M$ for control cows and CAL-treated cows during the first 15 DIM. Calcitriol did not affect the concentrations of NEFA in early lactation compared with controls (Figure 6B), and concentrations of NEFA in plasma averaged $561 \pm$ 40 and $616 \pm 44 \mathrm{mM}$ for control cows and CAL-treated cows, respectively, during the first 15 DIM. Similar to NEFA, CAL did not affect the concentrations of glucose in plasma in the first 2 weeks postpartum (Figure $6 \mathrm{C})$, and they averaged $54.1 \pm 1.1$ and $56.1 \pm 1.1 \mathrm{mM}$ for control and CAL, respectively. Moreover, concentrations of urea $\mathrm{N}$ in plasma did not differ between treat-

Table 2. Effect of treatment with calcitriol on yield and composition of colostrum and milk from the second milking postpartum from Holstein cows in experiment 2

\begin{tabular}{|c|c|c|c|c|}
\hline \multirow[b]{2}{*}{ Item } & \multicolumn{2}{|c|}{ Treatment $^{1}$} & \multirow[b]{2}{*}{ SEM } & \multirow[b]{2}{*}{$P$-value } \\
\hline & Control & Calcitriol & & \\
\hline Colostrum yield, $\mathrm{kg}$ & 7.34 & 6.63 & 1.16 & 0.63 \\
\hline \multicolumn{5}{|l|}{ Content } \\
\hline Fat, $\%$ & 4.37 & 4.21 & 0.33 & 0.72 \\
\hline True protein, $\%$ & 10.73 & 10.04 & 0.45 & 0.28 \\
\hline Lactose, $\%$ & 3.53 & 3.67 & 0.07 & 0.17 \\
\hline Net energy, Mcal $/ \mathrm{kg}$ & 1.14 & 1.10 & 0.04 & 0.43 \\
\hline SCS & 6.11 & 6.09 & 0.28 & 0.97 \\
\hline $\mathrm{Ca}, \mathrm{g} / \mathrm{L}$ & 1.91 & 1.99 & 0.09 & 0.51 \\
\hline $\mathrm{Mg}, \mathrm{g} / \mathrm{L}$ & 0.40 & 0.42 & 0.01 & 0.37 \\
\hline \multicolumn{5}{|l|}{ Yield } \\
\hline Fat, $\mathrm{kg}$ & 0.39 & 0.31 & 0.07 & 0.47 \\
\hline True protein, $\mathrm{kg}$ & 0.83 & 0.66 & 0.12 & 0.23 \\
\hline Lactose, $\mathrm{kg}$ & 0.26 & 0.27 & 0.05 & 0.93 \\
\hline $\mathrm{Ca}, \mathrm{g}$ & 14.6 & 13.2 & 2.5 & 0.65 \\
\hline $\mathrm{Mg}, \mathrm{g}$ & 3.0 & 2.8 & 0.5 & 0.78 \\
\hline Milk yield from second milking, $\mathrm{kg}$ & 6.24 & 5.28 & 0.60 & 0.22 \\
\hline \multicolumn{5}{|l|}{ Content } \\
\hline Fat, $\%$ & 3.85 & 3.78 & 0.31 & 0.86 \\
\hline True protein, $\%$ & 9.00 & 8.60 & 0.44 & 0.51 \\
\hline Lactose, $\%$ & 3.75 & 3.65 & 0.10 & 0.49 \\
\hline Net energy, Mcal $/ \mathrm{kg}$ & 1.01 & 0.98 & 0.04 & 0.54 \\
\hline SCS & 5.51 & 5.46 & 0.32 & 0.88 \\
\hline $\mathrm{Ca}, \mathrm{g} / \mathrm{L}$ & 1.77 & 1.76 & 0.06 & 0.81 \\
\hline $\mathrm{Mg}, \mathrm{g} / \mathrm{L}$ & 0.32 & 0.31 & 0.01 & 0.72 \\
\hline \multicolumn{5}{|l|}{ Yield } \\
\hline Fat, $\mathrm{kg}$ & 0.26 & 0.22 & 0.03 & 0.49 \\
\hline True protein, $\mathrm{kg}$ & 0.56 & 0.46 & 0.06 & 0.22 \\
\hline Lactose, $\mathrm{kg}$ & 0.24 & 0.20 & 0.02 & 0.24 \\
\hline $\mathrm{Ca}, \mathrm{g}$ & 10.7 & 9.2 & 1.1 & 0.27 \\
\hline $\mathrm{Mg}, \mathrm{g}$ & 2.0 & 1.7 & 0.2 & 0.32 \\
\hline
\end{tabular}

${ }^{1}$ Within $6 \mathrm{~h}$ after calving, cows received an injection of placebo (control) or $300 \mu \mathrm{g}$ of calcitriol. 
ments, and averaged $9.3 \pm 0.3$ and $9.3 \pm 0.3 \mathrm{mg} / \mathrm{dL}$ for control cows and CAL-treated cows, respectively, in the first 15 DIM (Figure 6D).

Urinary Excretion of Minerals. Treatment with CAL increased $(P=0.01)$ the excretion of $\mathrm{Ca}$ in urine in the first 7 DIM compared with control cows, and the daily loss averaged $0.52 \pm 0.26$ and $2.07 \pm 0.26 \mathrm{~g} / \mathrm{d}$ for control cows and CAL-treated cows, respectively, during the first 7 DIM (Figure 7A). Similarly, treatment with CAL increased $(P=0.02)$ the daily urinary loss of $t \mathrm{Mg}$, but this effect was observed only in the first 2 DIM (Figure 7B). Daily urinary loss of tMg averaged $4.49 \pm 0.42$ and $5.03 \pm 0.42 \mathrm{~g} / \mathrm{d}$ for control cows and CAL-treated cows, respectively, during the first 7 DIM.

Blood Cell Count and Neutrophil Function. Calcitriol increased $(P=0.04)$ the hematocrit compared with controls during the first 6 DIM, but concentration of hemoglobin did not differ between treatments (Table 4). The number of erythrocytes, reticulocytes, platelets, total leukocytes, or distinct types of leukocytes such as neutrophils, lymphocytes, and monocytes per microliter of blood did not differ between treatments. The CAL treatment tended $(P=0.07)$ to increase the concentration of eosinophils plus basophils in blood compared with control cows. The blood values for erythrocytes, leukocytes, and platelets were within the normal range expected for lactating dairy cows.
Treatments did not affect the percentage of neutrophils in blood with phagocytic activity during the first 6 DIM (control $=53.9 \pm 4.4$ vs. $\mathrm{CAL}=60.9 \pm 4.4 \%$; Figure $8 \mathrm{~A})$; however, CAL increased $(P=0.03)$ the MFI for number of bacteria phagocytized per neutrophil $($ control $=23,887 \pm 1,324$ vs. $\mathrm{CAL}=28,080 \pm$ 1,310; Figure 8C), and this response was more evident at 2 DIM. Furthermore, CAL increased $(P=0.03)$ the percentage of neutrophils in blood with oxidative burst activity (control $=31.9 \pm 2.7$ vs. $\mathrm{CAL}=40.6 \pm 2.7 \%$; Figure $8 \mathrm{~B}$ ), and this response was observed in the first 4 DIM. Calcitriol increased $(P=0.04)$ and tended $(P$ $=0.09)$ to increase the MFI for production of reactive oxygen species per neutrophil in blood compared with control cows on d 2 and 4 postpartum, respectively (Figure 8D).

\section{DISCUSSION}

Administration of a single $300-\mu \mathrm{g}$ dose of calcitriol within $6 \mathrm{~h}$ of parturition was efficacious and safe for increasing concentrations of $\mathrm{iCa}$ and $\mathrm{tCa}$ in the plasma of dairy cows in a sustainable manner, and reduced the daily prevalence rate of subclinical hypocalcemia in the first 3 DIM. Administration of $300 \mu \mathrm{g}$ of calcitriol increased concentrations of calcitriol in plasma similar to those observed in cows with clinical hypocalcemia

Table 3. Effect of treatment with calcitriol on performance of Holstein cows in experiment 2

\begin{tabular}{|c|c|c|c|c|c|c|}
\hline \multirow[b]{2}{*}{ Item } & \multicolumn{2}{|c|}{ Treatment $(\text { Trt })^{1}$} & \multirow[b]{2}{*}{ SEM } & \multicolumn{3}{|c|}{$P$-value } \\
\hline & Control & Calcitriol & & Trt & Day & Trt $\times$ day \\
\hline DMI, $\mathrm{kg} / \mathrm{d}$ & 19.9 & 19.4 & 0.6 & 0.50 & $<0.01$ & 0.71 \\
\hline Milk, kg/d & 34.0 & 34.1 & 1.0 & 0.94 & $<0.01$ & 0.08 \\
\hline $3.5 \% \mathrm{FCM}, \mathrm{kg} / \mathrm{d}$ & 38.2 & 38.1 & 1.2 & 0.88 & $<0.01$ & 0.19 \\
\hline ECM, $\mathrm{kg} / \mathrm{d}$ & 37.0 & 36.6 & 1.0 & 0.55 & $<0.01$ & 0.21 \\
\hline $3.5 \% \mathrm{FCM} / \mathrm{DMI}$ & 2.07 & 2.15 & 0.08 & 0.40 & $<0.01$ & 0.73 \\
\hline \multicolumn{7}{|l|}{ Milk fat } \\
\hline$\%$ & 4.35 & 4.27 & 1.00 & 0.55 & $<0.01$ & 0.21 \\
\hline $\mathrm{kg} / \mathrm{d}$ & 1.44 & 1.44 & 0.11 & 0.62 & $<0.01$ & 0.59 \\
\hline \multicolumn{7}{|l|}{ Milk true protein } \\
\hline$\%$ & 3.11 & 3.05 & 0.04 & 0.33 & $<0.01$ & 0.99 \\
\hline $\mathrm{kg} / \mathrm{d}$ & 1.04 & 1.02 & 0.03 & 0.53 & $<0.01$ & 0.10 \\
\hline \multicolumn{7}{|l|}{ Lactose } \\
\hline$\%$ & 4.66 & 4.63 & 0.03 & 0.35 & $<0.01$ & 0.53 \\
\hline $\mathrm{kg} / \mathrm{d}$ & 1.60 & 1.59 & 0.05 & 0.87 & $<0.01$ & 0.12 \\
\hline SCS & 3.62 & 3.53 & 0.44 & 0.89 & $<0.01$ & 0.74 \\
\hline \multicolumn{7}{|l|}{ Milk net energy } \\
\hline $\mathrm{Mcal} / \mathrm{kg}$ & 0.76 & 0.75 & 0.01 & 0.41 & $<0.01$ & 0.52 \\
\hline $\mathrm{Mcal} / \mathrm{d}$ & 25.6 & 25.3 & 0.8 & 0.70 & $<0.01$ & 0.12 \\
\hline \multicolumn{7}{|l|}{ BW } \\
\hline $\mathrm{kg}$ & 632.5 & 648.4 & 12.8 & 0.39 & $<0.01$ & 0.91 \\
\hline Change, $\mathrm{kg} / \mathrm{d}$ & -0.90 & -0.91 & 0.16 & 0.98 & $<0.01$ & 0.55 \\
\hline \multicolumn{7}{|l|}{ BCS, 1 to 5} \\
\hline Mean & 3.09 & 3.13 & 0.05 & 0.52 & $<0.01$ & 0.57 \\
\hline Change per week & -0.07 & -0.06 & -0.01 & 0.35 & $<0.01$ & 0.83 \\
\hline Energy balance, Mcal/d & -3.4 & -4.4 & 0.9 & 0.41 & $<0.01$ & 0.85 \\
\hline
\end{tabular}

${ }^{1}$ Within $6 \mathrm{~h}$ after calving, cows received an injection of placebo (control) or $300 \mu \mathrm{g}$ of calcitriol. 

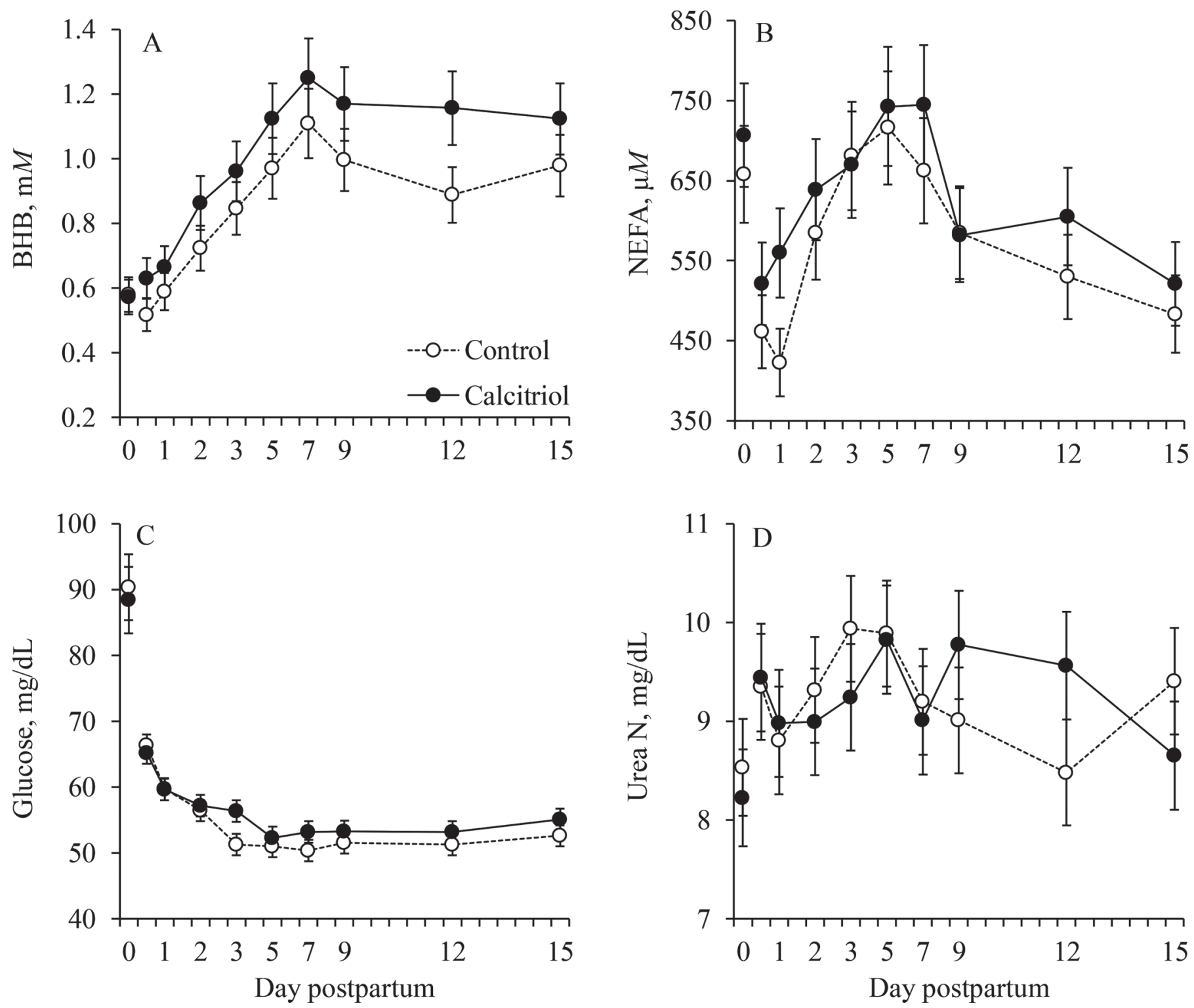

Figure 6. Concentrations of (A) BHB, (B) nonesterified fatty acids (NEFA), (C) glucose, and (D) urea N in plasma of dairy cows receiving an injection of placebo (control) or $300 \mu \mathrm{g}$ of calcitriol in experiment 2. (A) effects of treatment $(P=0.08)$, day $(P<0.001)$, and interaction between treatment and day $(P=0.99)$; $(\mathrm{B})$ effects of treatment $(P=0.34)$, day $(P<0.001)$, and interaction between treatment and day $(P=$ $0.61)$; (C) effects of treatment $(P=0.29)$, day $(P<0.001)$, and interaction between treatment and day $(P=0.44)$; (D) effects of treatment $(P$ $=0.98)$, day $(P=0.39)$, and interaction between treatment and day $(P=0.41)$. Error bars denote SEM.

(Horst et al., 1994), and concentrations remained elevated for approximately $3 \mathrm{~d}$, after which they returned to values below $50 \mathrm{pg} / \mathrm{mL}$. This elevated concentration of calcitriol in CAL-treated cows resulted in increases of blood iCa, plasma tCa, and tP in the first 3 to $7 \mathrm{~d}$ postpartum.

One of the issues with administration of calcitriol prepartum is the selected dose and the frequency of administration. The inability to predict the day of calving can mean that some cows receive multiple treatments of calcitriol, so that the exogenous calcitriol and elevations in blood Ca could limit endogenous production in a feedback mechanism, acting via a decrease in 25-hydroxyvitamin D $1 \alpha$-hydroxylase activity and an increase in 25-hydroxyvitamin D 24-hydroxylase activity (Nelson et al., 2016). Such repeated treatments result in increased risk of hypocalcemia after 1 or 2 DIM. Elevated calcitriol concentrations also suppress PTH concentrations, as observed with the CAL treatment in the current experiment. Excessive activation of the vitamin $\mathrm{D}$ receptor from massive dosing of prepartum cows with cholecalciferol also resulted in vitamin $\mathrm{D}_{3}$ 
Table 4. Effect of treatment with calcitriol on blood cell count of Holstein cows in experiment 2

\begin{tabular}{|c|c|c|c|c|c|c|}
\hline \multirow[b]{2}{*}{ Item } & \multicolumn{2}{|c|}{ Treatment $^{1}$} & \multirow[b]{2}{*}{ SEM } & \multicolumn{3}{|c|}{$P$-value } \\
\hline & Control & Calcitriol & & Treatment & Day & Treatment $\times$ day \\
\hline Hematocrit, \% & 29.7 & 31.3 & 0.5 & 0.04 & $<0.01$ & 0.72 \\
\hline Hemoglobin, g/dL & 4.6 & 4.8 & 0.3 & 0.41 & 0.39 & 0.68 \\
\hline Erythrocytes, $\times 10^{6} / \mu \mathrm{L}$ & 5.9 & 6.0 & 0.1 & 0.53 & 0.32 & 0.89 \\
\hline \multicolumn{7}{|l|}{ Reticulocytes } \\
\hline$\times 1,000 / \mu \mathrm{L}$ & 6.9 & 8.2 & 1.0 & 0.40 & 0.48 & 0.75 \\
\hline$\%$ & 0.13 & 0.16 & 0.03 & 0.37 & 0.56 & 0.81 \\
\hline Platelets, $\times 1,000 / \mu \mathrm{L}$ & 224 & 218 & 18 & 0.81 & 0.22 & 0.62 \\
\hline Leukocytes, $\times 1,000 / \mu \mathrm{L}$ & 15.3 & 15.1 & 1.4 & 0.94 & $<0.01$ & 0.58 \\
\hline \multicolumn{7}{|l|}{ Neutrophils } \\
\hline$\times 1,000 / \mu \mathrm{L}$ & 4.4 & 4.3 & 0.3 & 0.96 & $<0.01$ & 0.16 \\
\hline$\%$ & 30.1 & 28.2 & 2.5 & 0.60 & $<0.01$ & 0.45 \\
\hline \multicolumn{7}{|l|}{ Lymphocytes } \\
\hline$\times 1,000 / \mu \mathrm{L}$ & 8.2 & 8.3 & 1.0 & 0.95 & 0.93 & 0.52 \\
\hline$\%$ & 56.0 & 57.3 & 2.8 & 0.74 & $<0.01$ & 0.34 \\
\hline \multicolumn{7}{|l|}{ Monocytes } \\
\hline$\times 1,000 / \mu \mathrm{L}$ & 1.7 & 1.7 & 0.2 & 0.89 & $<0.01$ & 0.97 \\
\hline$\%$ & 12.3 & 12.1 & 0.8 & 0.88 & $<0.01$ & 0.92 \\
\hline \multicolumn{7}{|l|}{ Eosinophils and basophils } \\
\hline$\times 1,000 / \mu \mathrm{L}$ & 0.14 & 0.22 & 0.03 & 0.07 & $<0.01$ & 0.95 \\
\hline$\%$ & 1.0 & 1.3 & 0.2 & 0.35 & $<0.01$ & 0.33 \\
\hline
\end{tabular}

${ }^{1}$ Within $6 \mathrm{~h}$ after calving, cows received an injection of placebo (control) or $300 \mu \mathrm{g}$ of calcitriol.

toxicity with signs such as anorexia and metastatic calcification (Littledike and Horst, 1982). Therefore, excessive doses or repeated administrations of calcitriol pose a risk of toxicity and disruption of the vitamin $\mathrm{D}$ endocrine system. In the present experiment, CALtreated cows received only a single treatment immediately after calving.

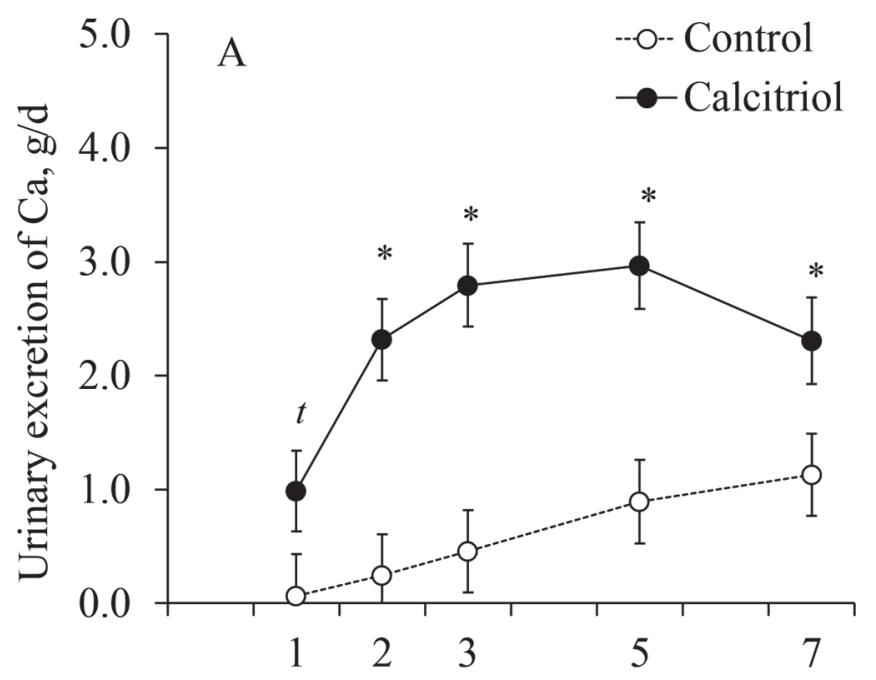

Day postpartum
In past experiments, calcitriol and other vitamin $\mathrm{D}_{3}$ analogs were fed or administered to dairy cows in the days preceding the expected date of calving with the aim of preventing clinical hypocalcemia, because the feeding of acidogenic diets prepartum was not a common practice (Hove and Kristiansen. 1982; Goff et al., 1988). Because clinical hypocalcemia can be prevented

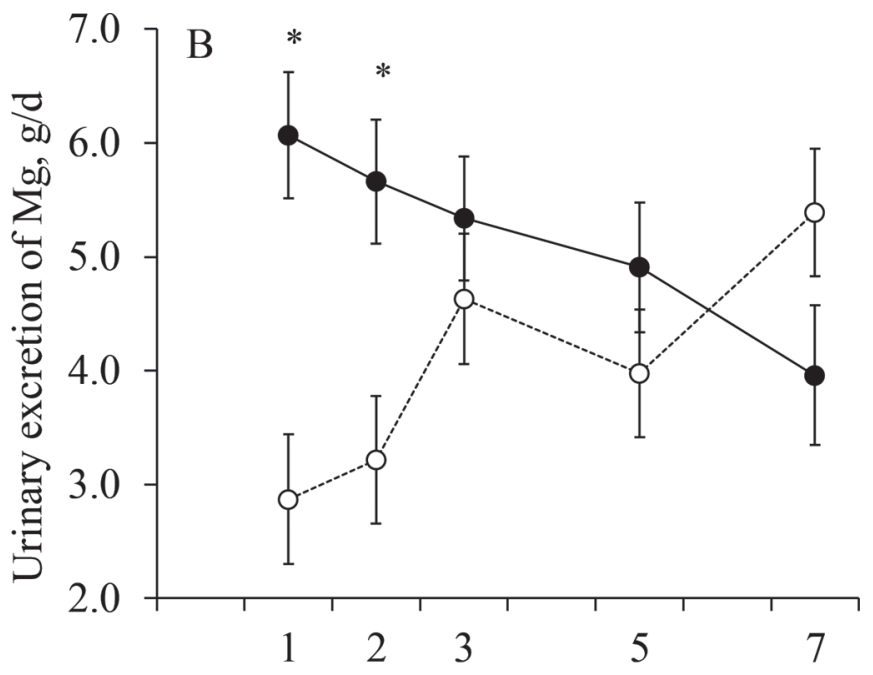

Day postpartum

Figure 7. Daily excretion of (A) total $\mathrm{Ca}$ and $(\mathrm{B})$ total $\mathrm{Mg}$ in urine of dairy cows receiving an injection of placebo (control) or $300 \mu \mathrm{g}$ of calcitriol in experiment 2. (A) Effects of treatment $(P=0.01)$, day $(P=0.06)$, and interaction between treatment and day $(P=0.01) ;(B)$ effects of treatment $(P=0.02)$, day $(P<0.001)$, and interaction between treatment and day $(P<0.001)$. Within a day, ${ }^{*}$ denotes difference between treatments $(P<0.05)$, and $t$ denotes a tendency to differ $(P=0.07)$. Error bars denote SEM. 

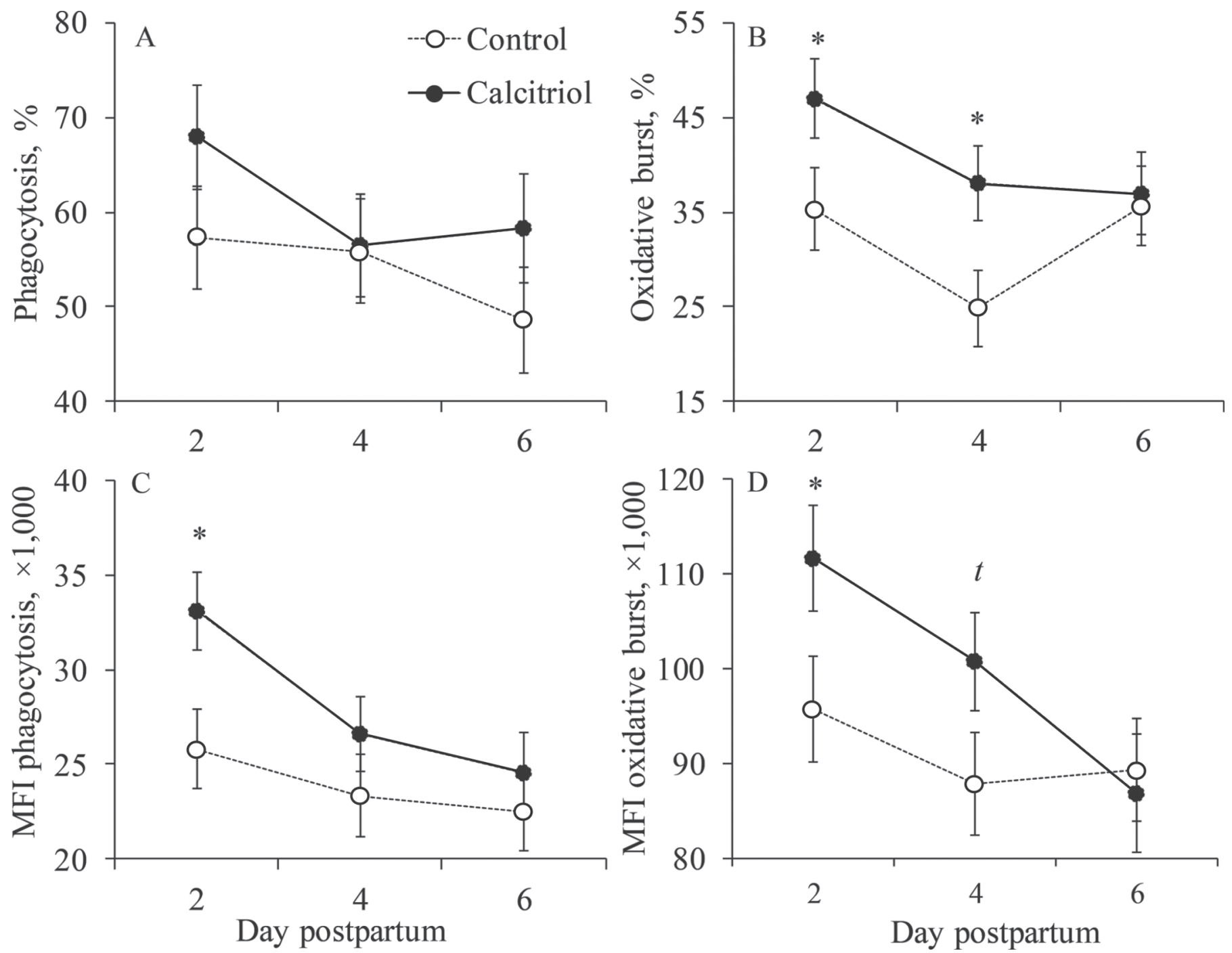

Figure 8. (A) Phagocytosis, (B) oxidative burst, (C) mean fluorescence intensity (MFI) for phagocytosis, and (D) MFI for oxidative burst in neutrophils from dairy cows receiving an injection of placebo (control) or $300 \mu \mathrm{g}$ of calcitriol in experiment 2. (A) Effects of treatment $(P=$ $0.17)$, day $(P=0.17)$, and interaction between treatment and day $(P=0.60)$; $(\mathrm{B})$ effects of treatment $(P=0.03)$, day $(P=0.06)$, and interaction between treatment and day $(P=0.24) ;(\mathrm{C})$ effects of treatment $(P=0.03)$, day $(P=0.01)$, and interaction between treatment and day $(P$ $=0.41)$; (D) effects of treatment $(P=0.06)$, day $(P=0.02)$, and interaction between treatment and day $(P=0.21)$. Within a day, ${ }^{*}$ denotes difference between treatments $(P<0.05)$, and $t$ denotes a tendency to differ $(P=0.09)$. Error bars denote SEM.

effectively by manipulating the prepartum DCAD with acidogenic salts (DeGaris and Lean, 2008; Goff, 2014), the strategy in the present experiment was to use calcitriol immediately after calving to further reduce the risk of subclinical hypocalcemia and improve innate immune function, which is known to be negatively affected by hypocalcemia in dairy cows (Martinez et al., 2012; Martinez et al., 2014). Because administration of CAL at calving took between 12 and $24 \mathrm{~h}$ to increase concentrations of $\mathrm{iCa}$ in blood, it would not have been efficient at preventing the decrease in blood $\mathrm{Ca}$ that occurs immediately before calving because of the sequestration of Ca by the mammary gland (Visek et al.,
1953), or following colostrum milking. Therefore, it is plausible to suggest that the successful use of calcitriol to improve Ca homeostasis when cows are treated after calving must be combined with dietary interventions that prevent clinical hypocalcemia, such as feeding of acidogenic diets prepartum.

Calcitriol increased concentrations of calcitriol, iCa, tCa, and tP in dairy cows within $24 \mathrm{~h}$ of treatment, and plasma tCa and tP concentrations remained elevated until 5 to 7 DIM in CAL-treated cows. The actions of calcitriol occur predominantly through the vitamin D receptor, which upregulates Ca transport and $\mathrm{Ca}$ binding proteins PMCA1b and Calbindin- $\mathrm{D}_{9 \mathrm{k}}$, such as in in- 
testine and kidney cells, and increases the release of $\mathrm{Ca}$ and $\mathrm{P}$ from bone via promotion of osteoclast activity. The combined actions of calcitriol in intestine, kidney, and bone cells presumably account for the increased $\mathrm{Ca}$ and $\mathrm{P}$ concentrations in CAL-treated cows. However, treatment with CAL did not increase the concentrations of CTX-1 in plasma, a marker of bone resorption, compared with control cows. Concentrations of CTX-1 increased almost $60 \%$ after calving in both treatments. Previous experiments using hydroxyproline, also a bone resorption marker, showed that calcitriol and its analogs did not increase plasma concentrations or urinary excretion of hydroxyproline in nonlactating cows (Goff et al., 1986). Furthermore, CAL-treated cows had reduced concentrations of PTH, and PTH has been shown to stimulate bone remodeling (Hustmyer et al., 1995). The lack of difference in CTX-1 between treatments suggests that the increases in concentrations of $\mathrm{iCa}, \mathrm{tCa}$, and $\mathrm{tP}$ observed with calcitriol were probably the result of increased intestinal absorption instead of bone resorption. That the absolute amounts of $\mathrm{Ca}$ and $\mathrm{P}$ reabsorbed by the kidneys may also have increased in CAL-treated cows, but the subsequent transient hypercalcemia induced with CAL treatment doubled the amount of tCa lost in urine in the first $7 \mathrm{~d}$ postpartum.

Calcium intake did not differ, because cows received the same diets pre- and postpartum, and DMI did not differ between treatments. Also, the loss of tCa in colostrum and milk did not differ between treatments. Because milk yield did not differ for the first 36 DIM, it is likely that loss of $\mathrm{Ca}$ and other minerals in milk were the same between treatments in early lactation. Therefore, the changes in blood Ca observed in CALtreated cows were likely the result of improved intestinal absorption.

Cows treated with CAL had smaller concentrations of $\mathrm{Mg}$ in plasma than control cows in the first 3 DIM. The reduced concentrations of $\mathrm{Mg}$ may be explained by renal handling of $\mathrm{Ca}$ and $\mathrm{Mg}$. Activation of Ca-sensing receptors induced by increases in $\mathrm{iCa}$ in the thick ascending limb of the Henle loop and distal convoluted tubules inhibits the $\mathrm{Na}^{+} / \mathrm{K}^{+} / 2 \mathrm{Cl}^{-}$cotransporter system, which is important for paracellular reabsorption of $\mathrm{Ca}$ and $\mathrm{Mg}$ (Dai et al., 2001). The expected changes in the $\mathrm{Na}^{+} / \mathrm{K}^{+} / 2 \mathrm{Cl}^{-}$cotransporter system induced by increases in $\mathrm{iCa}$ cause a reduction in the lumen-positive voltage, which reduces the paracellular mineral reabsorption in the kidney (Hebert et al., 1997). In fact, CAL increased urinary excretion of tMg. Thus, the increase in iCa combined with the reduced concentrations of PTH in CAL-treated cows resulted in increased urinary loss of $\mathrm{tMg}$, which likely explains the reduced concentrations of $\mathrm{tMg}$ in plasma compared with control cows in the first 3 DIM.
Calcitriol tended to increase serotonin concentrations. Serotonin plays a role in bone remodeling, and it is required for osteoclastogenesis (Chabbi-Achengli et al., 2012). Laporta et al. (2013) reported that concentrations of serotonin in blood were positively associated with serum concentrations of $\mathrm{iCa}$, and cows with clinical hypocalcemia had reduced concentrations of serotonin compared with cows without hypocalcemia. Furthermore, serotonin has been reported to regulate Ca transport in mammary epithelial cells during lactation (Laporta et al., 2014).

Subclinical hypocalcemia reduces DMI and compromises energy metabolism in dairy cows (Martinez et al., 2014). It was initially expected that administration of calcitriol would increase blood concentrations of iCa and eliminate subclinical hypocalcemia, which would benefit appetite in dairy cows. Nevertheless, results from the current experiment demonstrated that DMI and productive performance were unaffected by treatment of cows with CAL. In fact, cows treated with CAL had similar yields of milk and milk components, which resulted in no differences in energy balance or concentrations of NEFA, glucose, or urea $\mathrm{N}$ in plasma. Martinez et al. (2014) showed that subclinical hypocalcemia increased concentrations of NEFA in plasma, mediated by a depression in the release of insulin, in spite of increased glucose concentrations. Despite the benefits of CAL in reducing subclinical hypocalcemia in the first 3 DIM, it seems that it was not sufficient to attenuate the lipolytic signals and depress concentrations of NEFA in plasma. In fact, cows treated with CAL had slightly higher concentrations of BHB in plasma than control cows. Collectively, these results indicate that treatment with CAL immediately after calving did not benefit lactation performance or energy metabolism in dairy cows in the first month postpartum.

Results from the current experiment showed that treatment with CAL reduced the prevalence of subclinical hypocalcemia in the first 3 DIM by increasing concentrations of $\mathrm{iCa}$ and $\mathrm{tCa}$ in the blood of dairy cows, and improved neutrophils' phagocytic and killing activities. The increased demand for Ca during the peripartum period has been shown to decrease intracellular iCa stores in peripheral blood leukocytes (Kimura et al., 2006), and cows with clinical hypocalcemia had compromised leukocyte function (Ducusin et al., 2003; Kimura et al., 2006). Similarly, induction of subclinical hypocalcemia in dry cows reduced the intracellular replenishment of iCa in neutrophils and compromised function for at least $72 \mathrm{~h}$ after recovery from hypocalcemia (Martinez et al., 2014). Cows that develop subclinical hypocalcemia have reduced neutrophil function based on less phagocytosis and oxidative burst needed to kill pathogens (Martinez et al., 2012; Martinez et 
al., 2014). Ionized Ca plays a key role in the activation of neutrophils, and receptor-mediated transient increases in cytosolic iCa are required for the activation of phagocytes to clear invading pathogens. Increments in cytosolic iCa induce activation of membrane-associated superoxide anion NADPH oxidase, degranulation, and activation of phospholipases needed during the inflammatory response that contribute to the killing of phagocytized pathogens (Bréchard and Tschirhart, 2008). The increments in $\mathrm{iCa}$ during the first few days postpartum in CAL-treated cows in the present experiment likely favored an innate immune response and improved neutrophil function early postpartum. The elevated calcitriol concentrations in CAL-treated cows may also have had a direct influence on immune function, because immune cells express vitamin $\mathrm{D}$ receptor. In bovine monocytes, calcitriol increased the expression of inducible nitric oxide synthase, the chemokine RANTES (regulated on activation, normal T cell expressed and secreted), and several $\beta$-defensins genes (Nelson et al., 2010; Merriman et al., 2015). Indeed, intramammary infusion of $10 \mu \mathrm{g}$ of calcitriol increased expression of inducible nitric oxide synthase and $\beta$-defensins genes in milk somatic cells and in neutrophils and macrophages isolated from milk of treated cows (Merriman et al., 2017). The effects of intramammary calcitriol were observed in the absence of an increase in plasma tCa concentration, suggesting a localized direct effect on immune cells. Therefore, the combined effects of increasing concentrations of calcitriol and $\mathrm{iCa}$ might explain the benefits observed in neutrophil function in cows treated with calcitriol.

\section{CONCLUSIONS}

Administration of a single dose of $300 \mu \mathrm{g}$ of calcitriol immediately after calving increased the concentrations of calcitriol in plasma of dairy cows for approximately 3 d. Calcitriol was an efficacious and safe approach to increasing concentrations of $\mathrm{iCa}$ and tCa in blood of early postpartum dairy cows; it reduced the prevalence of subclinical hypocalcemia and improved measures of innate immune function. The dose did not seem to result in an important depression in blood Ca after the exogenous calcitriol cleared from blood, although concentrations of tCa were less for CAL-treated cows than for control cows between 12 and 15 DIM. Calcitriol increased urinary excretion of $\mathrm{Ca}$ and $\mathrm{Mg}$, which reduced tMg concentration in plasma. Neutrophil phagocytosis and oxidative burst improved by treating cows with calcitriol. Measures of production such as intake of DM, milk production and milk composition, and concentrations of analytes in plasma associated with energy metabolism did not differ between treatments, although concentration of BHB tended to increase in CAL-treated cows compared with controls. Collectively, results from the present experiment indicate that treatment of dairy cows with a single injection of $300 \mu \mathrm{g}$ of calcitriol is an alternative for minimizing subclinical hypocalcemia and enhancing innate immune function. Further experiments are needed to clarify the effects of calcitriol treatment on postpartum diseases and the carryover effects on productive and reproductive performance. Moreover, calcitriol treatment at calving may interact positively with other transitional nutrient management strategies but this still needs to be studied.

\section{ACKNOWLEDGMENTS}

The authors thank Sergei Sennikov (University of Florida) for assistance with laboratory analyses. We thank Raies A. Mier (University of Florida) for preparing the labeled Escherichia coli for neutrophil assays. The help of Todd Pritchard and the staff of the University of Florida Dairy Unit is greatly appreciated. Financial support for this experiment was provided by a grant from the Southeast Milk Check-Off Dairy Research and Education Projects.

\section{REFERENCES}

Allsop, T. F., and J. V. Pauli. 1985. Failure of 25-hydroxycholecalciferol to prevent milk fever in dairy cows. New Zeal. J. Exp. Agr. $13: 19-22$.

Bréchard, S., and E. J. Tschirhart. 2008. Regulation of superoxide production in neutrophils: Role of calcium influx. J. Leukoc. Biol. 84:1223-1237.

Chabbi-Achengli, Y., A. E. Coudert, J. Callebert, V. Geoffroy, F. Côté, C. Collet, and M. C. de Vernejoul. 2012. Decreased osteoclastogenesis in serotonin deficient mice. Proc. Natl. Acad. Sci. USA 109:2567-2572.

Curtis, C. R., H. N. Erb, and C. J. Sniffen. 1983. Association of parturient hypocalcemia with eight periparturient disorders in Holstein cows. J. Am. Vet. Med. Assoc. 183:559-561.

Dai, L. J., G. Ritchie, D. Kerstan, H. S. Kang, D. E. Cole, and G. A. Quamme. 2001. Magnesium transport in the renal distal convoluted tubule. Physiol. Rev. 81:51-84.

DeGaris, P. J., and I. J. Lean. 2008. Milk fever in dairy cows: A review of pathophysiology and control principles. Vet. J. 176:58-69.

Ducusin, R. J. T., Y. Uzuka, E. Satoh, M. Otani, M. Nishimura, S. Tanabe, and T. Sarashina. 2003. Effects of extracellular $\mathrm{Ca}^{2+}$ on phagocytosis and intracellular $\mathrm{Ca}^{2+}$ concentrations in polymorphonuclear leukocytes of postpartum dairy cows. Res. Vet. Sci. $75: 27-32$.

Elanco Animal Health. 2009. The 5-Point Body Condition Scoring System. Bulletin AI 10752. Elanco Animal Health, Greenfield, IN.

Ferguson, J. D., D. T. Galligan, and N. Thomsen. 1994. Principal descriptors of body condition score in Holstein cows. J. Dairy Sci. 77:2695-2703

Gast, D. R., R. L. Horst, N. A. Jorgensen, and H. F. DeLuca. 1979. Potential use of 1,25-dihydroxyvitamin $\mathrm{D}_{3}$ for prevention of parturient paresis. J. Dairy Sci. 62:1009-1013.

Gochman, N., and J. M. Schmitz. 1972. Application of a new peroxide indicator reaction to the specific, automated determination of glucose with glucose oxidase. Clin. Chem. 18:943-950. 
Goff, J. P. 2014. Calcium and magnesium disorders. Vet. Clin. North Am. Food Anim. Pract. 30:359-381.

Goff, J. P., R. L. Horst, D. C. Beitz, and E. T. Littledike. 1988. Use of 24-F1-,25-dihydroxyvitamin $\mathrm{D}_{3}$ to prevent parturient paresis in dairy cows. J. Dairy Sci. 71:1211-1219.

Goff, J. P., R. L. Horst, E. T. Littledike, A. Boris, and M. R. Uskokovic. 1986. Bone resorption, renal function and mineral status in cows treated with 1,25-dihydroxycholecalciferol and its 24-fluoro analogues. J. Nutr. 116:1500-1510.

Hebert, S. C., E. M. Brown, and H. W. Harris. 1997. Role of the $\mathrm{Ca}^{2+}$ sensing receptor in divalent mineral ion homeostasis. J. Exp. Biol. 200:295-302.

Hoenderop, J. G. J., D. Muller, A. W. C. M. Van Der Kemp, A. Hartog, M. Suzuki, K. Ishibashi, M. Imai, F. Sweep, P. H. G. M. Willems, C. H. Van Os, and R. J. M. Bindels. 2001. Calcitriol controls the epithelial calcium channel in kidney. J. Am. Soc. Nephrol. 12:1342-1349.

Horst, R. L., J. P. Goff, and T. A. Reinhardt. 1994. Calcium and vitamin D metabolism in the dairy cow. J. Dairy Sci. 77:1936-1951.

Horst, R. L., J. P. Goff, and T. A. Reinhardt. 2005. Adapting to the transition between gestation and lactation: Differences between rat, human and dairy cow. J. Mammary Gland Biol. Neoplasia 10:141-156.

Hove, K., and T. Kristiansen. 1982. Prevention of parturient hypocalcemia: Effect of a single oral dose of 1,25-dihydroxyvitamin $\mathrm{D}_{3}$. J. Dairy Sci. 65:1934-1940.

Hustmyer, F. G., D. C. Beitz, J. P. Goff, B. J. Nonnecke, R. L. Horst, and T. A. Reinhardt. 1995. In vivo parathyroid hormone stimulates in vitro bone resorption by bovine monocytes. J. Dairy Sci. 78:2700-2708.

Jørgensen, E., and A. R. Pedersen. 1998. How to obtain those nasty standard errors from transformed data - and why they should not be used. Biometry Research Unit-Internal report 7. Danish Institute of Agricultural Sciences, Aarhus, Denmark.

Jorgensen, N. A., R. L. Horst, H. F. DeLuca, and M. L. Ogilvie. 1978. 25-hydroxycholecalciferol for prevention of "milk fever" in dairy cows. Vet. Rec. 103:136-138.

Kimura, K., T. A. Reinhardt, and J. P. Goff. 2006. Parturition and hypocalcemia blunts calcium signals in immune cells of dairy cattle. J. Dairy Sci. 89:2588-2595.

Kitazawa, S., T. Kondo, and R. Kitazawa. 2003. Vitamin $\mathrm{D}_{3}$ supports osteoclastogenesis via functional vitamin $\mathrm{D}$ response elements of human RANKL gene promoter. J. Cell. Biochem. 89:771-777.

Laporta, J., K. P. Keil, C. M. Vezina, and L. L. Hernandez. 2014. Peripheral serotonin regulates maternal calcium trafficking in mammary epithelial cells during lactation in mice. PLoS One 9:e110190.

Laporta, J., S. A. E. Moore, M. W. Peters, T. L. Peters, and L. L. Hernandez. 2013. Short communication: Circulating serotonin (5HT) concentrations on day 1 of lactation as a potential predictor of transition-related disorders. J. Dairy Sci. 96:5146-5150.

Littledike, E. T., and R. L. Horst. 1982. Vitamin $D_{3}$ toxicity in dairy cows. J. Dairy Sci. 65:749-759.

Martinez, N., F. S. Lima, R. S. Bisinotto, L. F. Greco, E. S. Ribeiro, F. Maunsell, K. N. Galvão, C. A. Risco, and J. E. P. Santos. 2012. Evaluation of peripartal calcium status, energetic profile, and neutrophil function in dairy cows at low or high risk of developing uterine disease. J. Dairy Sci. 95:7158-7172.

Martinez, N., L. D. P. Sinedino, R. S. Bisinotto, R. Daetz, C. Lopera, C. A. Risco, K. N. Galvão, W. W. Thatcher, and J. E. P. Santos.
2016. Effects of oral calcium supplementation on mineral and acidbase status, energy metabolites and health of postpartum dairy cows. J. Dairy Sci. 99:8397-8416.

Martinez, N., L. D. P. Sinedino, R. S. Bisinotto, E. S. Ribeiro, G. C. Gomes, F. S. Lima, L. F. Greco, C. A. Risco, K. N. Galvao, D. Taylor-Rodriguez, J. P. Driver, W. W. Thatcher, and J. E. P. Santos. 2014. Effect of induced subclinical hypocalcemia on physiological responses and neutrophil function in dairy cows. J. Dairy Sci. 97:874-887.

Massey, C. D., C. Wang, G. A. Donovan, and D. K. Beede. 1993. Hypocalcemia at parturition as a risk factor for left displacement of the abomasum in dairy cows. J. Am. Vet. Med. Assoc. 203:852-853.

Melendez, P., G. A. Donovan, C. A. Risco, and J. P. Goff. 2004. Plasma mineral and energy metabolite concentrations in dairy cows fed an anionic prepartum diet that did or did not have retained fetal membranes after parturition. Am. J. Vet. Res. 65:1071-1076.

Merriman, K. E., M. F. Kweh, J. L. Powell, J. D. Lippolis, and C. D. Nelson. 2015. Multiple $\beta$-defensin genes are upregulated by the vitamin D pathway in cattle. J. Steroid Biochem. Mol. Biol. 154:120-129.

Merriman, K. E., M. B. Poindexter, M. F. Kweh, J. E. P. Santos, and C. D. Nelson. 2017. Intramammary 1,25-dihydroxyvitamin D3 treatment increases expression of host-defense genes in mammary immune cells of lactating dairy cattle. J. Steroid Biochem. Mol. Biol. https://doi.org/10.1016/j.jsbmb.2017.02.006.

Nelson, C. D., J. D. Lippolis, T. A. Reinhardt, R. E. Sacco, J. L. Powell, M. E. Drewnoski, M. O'Neil, D. C. Beitz, and W. P. Weiss. 2016. Vitamin D status of dairy cattle: Outcomes of current practices in the dairy industry. J. Dairy Sci. 99:10150-10160.

Nelson, C. D., T. A. Reinhardt, T. C. Thacker, D. C. Beitz, and J. D. Lippolis. 2010. Modulation of the bovine innate immune response by production of $1 \alpha, 25$-dihydroxyvitamin $\mathrm{D}_{3}$ in bovine monocytes. J. Dairy Sci. 93:1041-1049.

NRC. 2001. Nutrient Requirements of Dairy Cattle. 7th rev. ed., Natl. Acad. Press, Washington, DC.

Oetzel, G. R., and B. E. Muller. 2012. Effect of oral calcium bolus supplementation on early-lactation health and milk yield in commercial dairy herds. J. Dairy Sci. 95:7051-7065.

Pansu, D., C. Rocher, and F. Bronner. 1983. Duodenal and ileal calcium absorption in the rat and effects of vitamin D. Am. J. Physiol. 244:G695-G700.

Quinlan, K. P., and M. A. DeSesa. 1955. Spectrophotometric determination of phosphorus as molybdovanadophosphoric acid. Anal. Chem. 27:1626-1629.

Reinhardt, T. A.. J. D. Lippolis, B. J. McCluskey, J. P. Goff, and R. L. Horst. 2011. Prevalence of subclinical hypocalcemia in dairy herds. Vet. J. 188:122-124.

Risco, C. A., J. P. Reynolds, and D. Hird. 1984. Uterine prolapse and hypocalcemia in dairy cows. J. Am. Vet. Med. Assoc. 185:15171519.

Valadares, R. F. D., G. A. Broderick, S. C. Valadares Filho, and M. K. Clayton. 1999. Effect of replacing alfalfa silage with high moisture corn on ruminal protein synthesis estimated from excretion of total purine derivatives. J. Dairy Sci. 82:2686-2696.

Visek, W. J., R. A. Monroe, E. W. Swanson, and C. L. Comar. 1953. Calcium metabolism in dairy cows as studied with $\mathrm{Ca}^{45}$. J. Dairy Sci. 36:373-383 